\title{
Aspirin: a review of its neurobiological properties and therapeutic potential for mental illness
}

\author{
Michael Berk ${ }^{1,2,3,4^{*}}$, Olivia Dean ${ }^{1,2,4}$, Hemmo Drexhage ${ }^{5}$, John J McNeil ${ }^{6}$, Steven Moylan ${ }^{1}$, Adrienne O'Neil ${ }^{1,6}$, \\ Christopher G Davey ${ }^{3}$, Livia Sanna ${ }^{1}$ and Michael Maes ${ }^{1,7}$
}

\begin{abstract}
There is compelling evidence to support an aetiological role for inflammation, oxidative and nitrosative stress (O\&NS), and mitochondrial dysfunction in the pathophysiology of major neuropsychiatric disorders, including depression, schizophrenia, bipolar disorder, and Alzheimer's disease (AD). These may represent new pathways for therapy. Aspirin is a non-steroidal anti-inflammatory drug that is an irreversible inhibitor of both cyclooxygenase (COX)-1 and COX-2, It stimulates endogenous production of anti-inflammatory regulatory 'braking signals', including lipoxins, which dampen the inflammatory response and reduce levels of inflammatory biomarkers, including Creactive protein, tumor necrosis factor- $\alpha$ and interleukin (IL)-6, but not negative immunoregulatory cytokines, such as IL-4 and IL-10. Aspirin can reduce oxidative stress and protect against oxidative damage. Early evidence suggests there are beneficial effects of aspirin in preclinical and clinical studies in mood disorders and schizophrenia, and epidemiological data suggests that high-dose aspirin is associated with a reduced risk of AD. Aspirin, one of the oldest agents in medicine, is a potential new therapy for a range of neuropsychiatric disorders, and may provide proof-of-principle support for the role of inflammation and O\&NS in the pathophysiology of this diverse group of disorders.
\end{abstract}

Keywords: aspirin, depression, schizophrenia, dementia, inflammation, cytokines, neuroprogression, treatment, COX

\section{Introduction}

Historically, treatment options for common neuropsychiatric disorders, including depression, schizophrenia, and bipolar disorder, have focused on medications that modify the activity of monoamine neurotransmitter systems. Monoamines may play a large role in the pathophysiology of these disorders, but the monoaminergic theory of illness has failed to deliver novel agents beyond the limited treatment options currently available. There is now a clear body of recent evidence to support an etiologic role for other factors in the pathophysiology of depression, schizophrenia, and bipolar disorder, including oxidative and nitrosative stress (O\&NS), mitochondrial dysfunction, and activation of the immune-inflammatory system.

The immune system is classically divided into the innate and adaptive arms. The innate immune arm is the

\footnotetext{
* Correspondence: mikebe@barwonhealth.org.au

'School of Medicine, Deakin University, 75 Pigdon's Road, Waurn Ponds, Geelong, Victoria, 3216, Australia

Full list of author information is available at the end of the article
}

first line of defense against pathogens, and provides a rapid response with limited specificity. Key players in the innate immune system are defense cells (such as neutrophils, monocytes, macrophages, natural killer cells, and mast cells), and soluble factors, of which acute-phase proteins, complement, and various inflammatory cytokines (such as interferon (IFN) $\alpha$, tumor necrosis factor (TNF)- $\alpha$, interleukin (IL)-1 $\beta$, IL-6, and IL-8) are examples. Monocytes are closely related to macrophages, and collectively these cells are often referred to as the "mononuclear phagocyte system (MPS)'. The main descendants of these circulating monocytes are the macrophages, which occur in virtually all organs, and are present as microglia in the brain [1].

If the innate system fails to resolve the infection, the adaptive system will be triggered by the cells of the innate immune system. Dendritic cells pick up antigens at the site of infection, travel through the lymphatics to the lymph node, and present the collected antigen to cells of the adaptive immune system. The adaptive immune
C Biomed Central

ㄷ 2013 Berk et al; licensee BioMed Central Ltd. This is an Open Access article distributed under the terms of the Creative Commons Attribution License (http://creativecommons.org/licenses/by/2.0), which permits unrestricted use, distribution, and reproduction in any medium, provided the original work is properly cited. 
system is antigen-specific, provides a memory, and is typically activated a few days later than the innate system.

Inflammation, particularly the M1 macrophage response, is accompanied by increased levels of free radicals and O\&NS, creating a state in which levels of available antioxidants are reduced. Activation of the immuneinflammatory and O\&NS pathways and lowered levels of antioxidants are key phenomena in clinical depression (both unipolar and bipolar), autism, and schizophrenia [2-4]. Indeed, there is now strong evidence of the involvement of a progressive neuropathologic process in these conditions, with stage-related structural and neurocognitive changes well described for each. Incorporation of these wider factors into traditional monoamine neurotransmitter-system models has facilitated a more comprehensive model of disease, capable of explaining the observed process of neuroprogression. This understanding has facilitated the identification of new therapeutic targets and treatments that have the potential to interrupt the identified neurotoxic cascades [5-8]. The neuroprotective potential is one of the key promises of agents that target the components of the cascade.

One of the most commonly used pharmaceuticals in medicine, acetylsalicylic acid (aspirin), is an agent that may be capable of interrupting this neurotoxic cascade. Aspirin exerts its effects on the inflammatory cascades, irreversibly inhibiting cyclooxygenase (COX)-1, and modifying enzyme activity of COX-2, suppressing production of prostaglandins and thromboxanes [9]. These anti-inflammatory and anti-platelet mechanisms have been found to have positive effects on the risk of atherosclerosis, heart disease [10], stroke, and potentially, some cancers [11]. Given that similar disease mechanisms may underwrite the pathophysiology of major neuropsychiatric disorders, it is possible that aspirin, by interrupting neurotoxic cascades, could be a potential candidate for secondary prevention. In this review, we assess the evidence base supporting inflammatory and oxidative-stress disturbance in major neuropsychiatric disorders, and propose how aspirin may alter such pathways. Other reviews that have explored the use of somatic drugs for psychiatric diseases have placed a strong focus on COX-2 as the most important and powerful anti-inflammatory [12], but in this paper, we propose that COX-1 is in fact the key component in neurodegeneration and neuroinflammation, and thus a potential target for therapeutic intervention [12]. In addition, we identify some early indications of the preventative effect of aspirin on neuropsychiatric disorders.

\section{Inflammation and redox dysregulation in mood disorders}

There is a large body of data showing that stress and depression are associated with both increased immune activation and impaired immune function [13]. To date, immune function in individuals with major depressive disorder (MDD) has been investigated by assessing levels of pro-inflammatory and acute-phase proteins [14]. Studies have shown that levels of interleukin (IL)-6 and C-reactive protein (CRP), and the immunologic complement component $4(\mathrm{C} 4)$, but not $\mathrm{C} 3$, are significantly raised in patients with depression compared with controls [14]. Because increased levels of CRP predict the subsequent risk for de novo depression, these findings suggest that the documented immune findings are not merely epiphenomena of depression, but actually contribute to the genesis of the disorder [15]. A recent metaanalysis of cytokine studies in MDD showed that the cytokines IL- 6 and TNF- $\alpha$ were increased [16]. There is evidence that the pro-inflammatory cytokine IL-1 $\beta$ and the pro-inflammatory chemokine CCL2 are increased in bipolar disorder $[17,18]$.

Additional evidence for a central role of cytokines in depression derives from studies comprising healthy volunteers. For participants given infusions of endotoxin to induce the release of pro-inflammatory cytokines, there was a significant relationship between induced cytokine levels and emergence of mood-disorder symptoms [19]. Similarly, giving psychiatrically healthy individuals treatment with exogenous cytokines (IL-2, IFN- $\alpha$ and TNF- $\alpha$ ) induced the classic behavioral and cognitive phenotype of a mood disorder, including depressed mood state, mania, increased stress reactions, cognitive impairment, and reduced motivation [20]. Recently, antidepressant treatment was shown to reduce levels of the inflammatory markers levels CRP and IL-6 in patients with MDD [21,22], while persistently raised levels of inflammatory markers were associated with lack of treatment response [23]. Indeed, such findings suggest an immunomodulatory role for antidepressant medication, and provide support for the use of immune interventions that directly address this aspect of the pathophysiology of depression.

There are equally extensive data on the relationship between oxidative stress (OS) and depression. Compared with healthy controls, individuals experiencing major depressive episodes (MDEs) have significantly increased levels of markers of oxidative damage, including lipid-peroxidation products [24-27], the oxidized DNA marker 8hydroxy-2'-deoxyguanosine [28], and depleted omega-3 fatty acids (indicative of oxidative damage to erythrocyte membranes) [29]. Altered antioxidant levels are also seen in MDEs, including lower levels of serum vitamins $C$ and $E[30,31]$ and albumin [32], and altered levels of the antioxidative enzymes superoxide dismutase (SOD) [24-26,33], glutathione reductase (GR) and glutathione peroxidase (GSH-Px) [24]. A higher OS index, determined by the ratio of total plasma peroxide to total plasma 
antioxidant potential, is seen in drug-free patients with MDD [34]. Lastly, positive correlations have been found between depressive severity scores and OS index values [34], and between the severity of depression and the extent of changes in oxidative indices [24,26,28,31].

Normalization of oxidative parameters with the resolution of depression has been reported in two studies, in which it was found that baseline measures of antioxidant enzymes and lipid peroxidation were increased and vitamin C levels decreased in patients with MDE compared with controls $[24,25]$. Antidepressant treatment improved depressive symptoms, and was also associated with significant amelioration of oxidative parameters, corroborating findings from other studies [33]. Further supporting this, preclinical studies have shown that established antidepressant agents display antioxidant properties [35-38]. The evidence of a pathophysiological role of OS in MDD provides preliminary support for the use of antioxidant mechanisms as an additional therapeutic pathway.

\section{Inflammation and redox dysregulation in schizophrenia}

In schizophrenia, as in depression, there is long-standing evidence to suggest a major role for OS and, to a lesser extent, inflammation; reduced levels of antioxidants, such as glutathione, have been reported as early as 1934 [39]. Since these early findings, there has been a plethora of studies indicating altered levels of antioxidants, including the major antioxidants SOD, GSH-Px, and catalase, in addition to glutathione [40]. Lipid peroxidation is evidenced by the increased levels of malondialdehyde (MDA) and thiobarbituric acid that are seen in patients with schizophrenia. In addition, protein carbonylation and DNA damage is increased, leading to activation of apoptotic pathways, further disrupting normal brain function. Moreover, genetic polymorphisms have been identified that further implicate oxidative factors in the pathophysiology of schizophrenia. Polymorphisms in the glutamate-cysteine ligase gene, whose protein product is responsible for glutathione synthesis, occurs in bipolar disorder [41] and schizophrenia [42], but not in depression [43]. In a similar manner to its relationship with depression, positive correlations exist between levels of OS and symptom severity [40].

Although there is a substantial body of literature regarding maternal and prenatal inflammation and their role in schizophrenia, it has only been comparatively recently that the roles of inflammation in schizophrenia have been intensively investigated. Infectious agents including Toxoplasma gondii, Chlamydia, bornavirus cytomegalovirus, and influenza seem to increase the risk for schizophrenia, but it is possible that the immune response itself rather than the infection mediates this effect [44]. Raised maternal levels of the pro-inflammatory cytokine IL- 8 during pregnancy are associated with an increased risk for schizophrenia in the offspring, independent of the cause of inflammation [45]. The glutamatergic and dopaminergic systems, known to be dysregulated in schizophrenia, have a modulating effect on the immune system and on tryptophan-kynurenine metabolism, both of which are involved in the pathophysiology of schizophrenia [46]. Markers of inflammatory processes have been found in post-mortem studies of brains from patients with schizophrenia [47].

Pro-inflammatory changes have been described in schizophrenia; a recent meta-analyses of cytokine studies in schizophrenia showed that cytokines such as IL-12, TNF- $\alpha$, IFN- $\gamma$ and soluble CD25 are raised in and are trait markers of schizophrenia [48], whereas IL-1 $\beta$, IL- 6 and TGF- $\beta$ are state markers of acute schizophrenia [48]. Serum levels of the monocyte/macrophage cytokines, chemokines and adipokines CCL2, CCL4, TNF- $\alpha$, IL-1 $\beta$, IL-6, leptin, adiponectin, pentraxin-related protein (PTX3), plasminogen activator inhibitor (PAI)-1, osteoprotegerin (OPG) and intercellular adhesion molecule (ICAM)-1 were measured in individuals with chronic schizophrenia and compared with levels in healthy controls $(n=138)$. Levels of all measured immune compounds except PAI-1 and OPG were increased in the patients with schizophrenia. Multivariate analysis showed that these increases were linked to gender (ICAM-1, leptin, TNF- $\alpha$ and adiponectin), a higher body mass index (leptin, adiponectin), presence of hyperglycemia or diabetes (CCL4 and OPG), reduced high-density lipoprotein cholesterol or increased triglyceride (adiponectin and PTX3) levels, or presence of metabolic syndrome (CCL2, leptin, and adiponectin). IL-1 $\beta$ and IL- 6 were the only immune compounds found to be increased in the serum of patients not affected by any of these aforementioned factors. Although many of the immune compounds were found to be linked to (components of) metabolic syndrome, the most dominant linkage was found with schizophrenia itself, confirming earlier reports of increased monocyte/macrophage activation being a key component for understanding the pathogenesis of schizophrenia, consistent with the meta-analysis showing that IL-1 $\beta$ and IL-6 are trait markers of schizophrenia. Interestingly, previous work has shown that serum IL-6 levels seem to correlate with a poorer prognosis [49]. Positron emission tomography (PET) imaging studies using the ligand PK11195, a marker of microglial activation, have also suggested an inflammatory process in schizophrenia [50].

\section{Inflammation and redox dysregulation in Alzheimer's disease}

Alzheimer's disease (AD) is the most common cause of dementia in the elderly population, with over 33 million people affected worldwide [51]. AD is characterized by two major neuropathologic changes: deposition of intracellular neurofibrillary tangles composed of tau protein, 
and extracellular $\beta$-amyloid plaques [52]. The disease is also characterized by activation of astrocytes and microglia, which leads to production of a range of pro-inflammatory substances, including cytokines, chemokines, thromboxanes, and reactive oxygen species (ROS) [53], which over time may lead to cellular damage. It is suggested that deposition of $\beta$-amyloid plaques and tau protein (as neurofibrillary tangles) induces a chronic inflammatory state that is derived primarily from efforts to clear this debris [52]. During this chronic inflammatory state, substances released by astrocytes and microglia, such as ROS, nitric oxide (NO), and proteolytic enzymes, can not only cause direct toxic effects to the surrounding neuronal architecture, but also enhance further production of beta-amyloid, potentially contributing to disease progression. This process seems to involve both an upregulation in $\beta$-amyloid-42 production, and decreased production of soluble amyloid precursor protein, which potentially exerts neuroprotective effects [54]

Similar to psychiatric disorders, the interaction between inflammatory and OS responses appears to be important in $\mathrm{AD}$. A reciprocal relationship seems to exist between beta-amyloid and OS, with both augmenting production of the other $[55,56]$. In addition, patient's with AD appear to exhibit lower levels of antioxidant substances and enzymes early in the disease course [57], which, when coupled with the declining function of antioxidant defenses in key brain regions with advancing age [58], may predispose those with AD to OS mediated damage.

\section{The association between psychiatric disease, dementia, and auto-immunity}

To further support a role for therapeutic agents targeting inflammation in psychiatry, there is a large body of evidence linking autoimmune disease to psychiatric disorders. For example, clinical depression is associated with diverse autoimmune disorders, including diabetes type 1 and 2, inflammatory bowel disease, psoriasis, rheumatoid arthritis, atherosclerosis, lupus erythematosus, and multiple sclerosis (MS) [59]. Patients with clinical depression have a high degree of auto-immunity directed against a number of different selfepitopes, including serotonin and phospholipids (for example, cardiolipin and antinuclear factor) [60]. Recently, a new type of autoimmune response has been described, which is an autoimmune response secondary to O\&NS damage [61-63]. Thus, it is possible that increased O\&NS levels may damage endogenous molecules, such as fatty acids and proteins, thereby changing their structure. As a consequence, the O\&NS-modified self determinants may be rendered immunogenic, and an autoimmune response is then directed against the modified epitopes (neo-epitopes) [61]. For example, clinical depression is accompanied by IgG-mediated immune responses directed against oxidized low-density lipoprotein. Moreover, there is an association between this kind of autoimmune response and progression (or staging) of depression. Consequently, some of these autoimmune responses are significantly higher in depressed individuals with chronic depression (duration of $>2$ years) compared with patients who are depressed but do not have chronic depression [60]. These findings suggest that O\&NS damage, the consequent formation of neo-epitopes, an enhancement of the natural autoimmune response, and even a transition to pathological damaging auto-immunity increase the risk of neuroprogression and of chronic depression.

For schizophrenia, there is a parallel evidence base for an association with auto-immunity. In a large Danish national study, individuals with schizophrenia had a $45 \%$ higher chance of developing an organ-specific autoimmune disease, including thyroid autoimmune disease [64]. Moreover, these autoimmune diseases were also more prevalent in the parents of these individuals with schizophrenia. These findings not only imply a genetic component, with family members having a higher chance of developing such autoimmune disease, but indicate a putative shared immune pathogenesis of psychiatric disorder and organ-specific auto-immunity. Although organ-specific autoimmune diseases have been reported to have a higher prevalence in patients with schizophrenia, there are also numerous reports of a negative cooccurrence of schizophrenia and rheumatoid arthritis, which is a systemic autoimmune disorder, and the underlying immune mechanism is as yet unknown [65]. A number of autoantibodies are significantly higher in patients with schizophrenia compared with controls, especially those related to autoimmune responses directed against neuronal targets [66-68].

Evidence from the literature on bipolar disorder also supports the role of a genetic component; patients with bipolar disorder and their relatives have been shown to be more prone to develop thyroid auto-immunity, and this association is not attributable to the use of lithium or to the severity of psychiatric symptoms [69-71]. Moreover, in addition to a higher prevalence of thyroid autoantibodies, patients with bipolar disorder have a higher prevalence of organ-specific autoantibodies, including autoantibodies to hydrogen/potassium ATP and glutamic acid decarboxylase-65 [72]. The aforementioned Danish national study [64] confirmed these findings by showing an association of bipolar disorder with a family history of pernicious anemia, and with presence of Guillain-Barré syndrome, inflammatory bowel disease, and autoimmune hepatitis in individual patients.

Collectively, these findings imply shared immune pathogenic factors for mood disorders, schizophrenia, and organ-specific autoimmune diseases. One of these shared factors is thought to be an intrinsically high 
activation set-point for the MPS. It is thought that the high activation set-point of these cells of the MPS can be down-regulated by aspirin.

\section{Activated circulating monocytes in psychiatric disorders}

There is emerging evidence that the MPS is activated in patients with psychiatric disease. Early reports show that the number of circulating monocytes is aberrant in patients with schizophrenia. Rothermundt et al., reported a slight increase in the mean absolute and relative monocyte counts [73], and others have supported these observations, showing the presence of monocytosis and a higher number of CD14+ cells in non-medicated patients with schizophrenia and in children with psychosis $[74,75]$. In contrast to schizophrenia, higher numbers of CD14+ monocytes could not be found in bipolar disorder $[17,76]$, yet gene-expression studies identified activation of the circulating cells. Two gene-expression profiling studies $[17,18]$ have been carried out on purified monocytes taken from patients with psychiatric illness (56 with bipolar disorder and 27 with schizophrenia) and matched healthy controls. In sum, aberrant expression of 34 genes was detected, which mutually correlated and formed an immune-activation monocyte gene-expression signature, consisting of pro-inflammatory cytokines and compounds (for example, IL-1 $\beta$, IL-6 and COX2), inflammatory regulator molecules (for example, NAB-2), various chemokines (for example, chemokine ( $\mathrm{C}-\mathrm{C}$ motif) ligand (CCL)2), adhesion/motility factors (for example, cell division control protein 42 homolog; CDC42), and inflammatory transcription factors (for example, early growth response protein (EGR)3). The overexpression of monocyte activation genes was particularly evident in active cases, that is, in patients with mania, active melancholic depression, or active psychosis $[17,18]$.

\section{Activated microglia in psychiatric disorders}

Although histomorphologic signs of an abnormal inflammatory activation of microglia have been found in post-mortem studies on patients with major psychiatric disorders, these studies are limited and controversial.

A post-mortem study on the brains of patients with schizophrenia who had committed suicide during an episode of acute psychosis found an increased density of microglia in the tissue [77]. Three other studies reported increased microglial activation in patients with schizophrenia [78-80], whereas another three did not find an activation state of microglia [81-83]. A drawback of some of these post-mortem studies is that they were performed on old to very old individuals, and might not reflect the pathophysiology of acute exacerbations of psychiatric illness.
To date, only two histological studies have analyzed patients with affective disorders. A qualitative study of human leukocyte antigen (HLA)-DR showed increased expression of this surface marker on the microglia of the hippocampus and prefrontal cortex of patients with depression [78].

More recently, increases in the expression of quinolinic acid (QUIN) have been identified in ramified microglia in sub-regions of the anterior cingulate cortex of patients with severe depression [84]. The production of microglial QUIN from tryptophan was increased in the subgenual anterior cingulate cortex and anterior midcingulate cortex, but not in the pregenual anterior cingulate cortex of patients with major depression. A similar trend was seen for bipolar disorder. QUIN is a breakdown product of the tryptophan pathway, which is further broken down to $\mathrm{NAD}+$, and is primarily produced by activated microglial cells. A key enzyme for the production of QUIN in the microglia is indoleamine 2,3-dioxygenase (IDO), which IDO is activated by pro-inflammatory cytokines including IFN- $\gamma$, IL-1, IL- 6 , and TNF- $\alpha$.

In addition to post-mortem studies, techniques using PET have been used to study microglia activation in patients in real time. A PET tracer. [11C]-PK11195, binds to the mitochondrial translocator protein, whose expression is increased in activated microglia [85]. This technique has already been used successfully in several patient and animal studies of neuropsychiatric disorders [86], which show that immune-activation ('inflammatory') lesions occur in brain regions that are related to the specific disease process. For example, in schizophrenia, microglial activation is found in the hippocampal area, where functions such as immediate memory and sensory-emotional integration are impaired. Interestingly, these focal changes are found only in patients with acute psychosis, in whom cognitive impairment is most prominent [87], and not in patients who have recovered from psychosis [50], who show a global brain inflammatory effect.

Using PET, microglia activation has also been found in brain disorders such as AD, HIV-associated dementia, Parkinson's disease (PD), multisystem atrophy, MS, herpes encephalitis, traumatic brain injury, and stroke [88,89]. In addition, microglial activation is also found in peripheral disorders such as hepatitis, thiamine deficiency, and hepatic encephalopathy [90-92], and even after sleep loss [93].

An abnormal inflammatory activation of microglia can be detrimental for neurogenesis and synaptogenesis through lack of provision of neuronal growth factors or through production of neurotoxic factors and cytokines [94]. Mouse mutants in which microglia are in an activated state during prenatal development (CD200KO and DAP12KO mice) have altered levels of glutamate receptors, resulting in impaired long-term potentiation 
and hippocampal transmission [95-97]. In favor of a direct detrimental action of inflammatory cytokines on neuronal development, in vitro work has shown that cytokines such as IL-6, IL-18, and TNF- $\alpha$ can affect neuronal proliferation, survival, and aspects of differentiation such as neurite outgrowth and gene-expression patterns $[98,99]$.

\section{Working mechanisms of psychotropic medications}

For unipolar and bipolar depression, it is understood that the working mechanisms of classic antidepressants and new putative antidepressants are at least partly explained by their effects on various immune-related pathways, including: 1) reducing inflammatory responses characterized by increased levels of TNF- $\alpha$, IL-1 and IL-6; 2) attenuating cell-mediated immune activation and T-helper (Th) 1 and Th17 responses while increasing responses of regulatory $\mathrm{T}$ cells; 3 ) reducing O\&NS processes and increasing the total antioxidative capacity; 4) protecting against damage to mitochondria and mitochondrial DNA; and 5) attenuating neuroprogressive processes [100]. The same immunoinflammatory, O\&NS and neuroprogressive pathways play a role in schizophrenia [101]. Therefore, it has been suggested that targeting the aforementioned pathways in conjunction with dopamine receptor 2 and 5-hydroxytryptamine receptor 2 may be a treatment approach for schizophrenia [101].

\section{Working mechanisms of aspirin}

Aspirin is a non-steroidal anti-inflammatory drug (NSAID), and an irreversible inhibitor of both COX-1 and COX-2. It is more potent in its inhibition of COX-1 than COX-2, and targeting COX-2 alone may be a less viable therapeutic approach in neuropsychiatric disorders such as depression [102]. COX-2 inhibitors may theoretically cause neuroinflammatory reactions, and potentially might augment the Th1 predominance, increase O\&NS levels and O\&NS-induced damage, decrease antioxidant defenses, and even aggravate neuroprogression [102]. In addition, COX-2 inhibition may interfere with the resolution of inflammation [103]. Thus, COX-2 inhibition decreases the production of prostaglandin E2 (PGE2), which drives the negative immunoregulatory effects on ongoing inflammatory responses. In autoimmune arthritis, for example, PGE2 is part of a negative-feedback mechanism that attenuates the chronic inflammatory response [103]. Therefore, in order to understand the clinical efficacy of aspirin in neuropsychiatric disorders such as depression and schizophrenia, it is more important to consider how its inhibition of COX-1 affects the five aforementioned pathways. This is supported by data suggesting lower response rates to antidepressants in people receiving NSAIDs [104], but is at odds with some recent studies suggesting a benefit for celecoxib, a COX2 inhibitor, in several disorders including autism and depression $[105,106]$. In the following sections, we will discuss the effects of aspirin on these pathways.

\section{Aspirin and the suppression of activated cells of the mononuclear phagocyte system}

It is relevant to consider the inflammatory reaction as a biphasic process, with an initial phase of induction and a second phase of resolution. During the initial phase of inflammation, eicosanoids including prostaglandins and leukotrienes play an important role as local mediators in the development of an inflammatory condition, evoking potent chemotactic responses from leukocytes, the activation of which is coupled to the production of pro-inflammatory cytokines at sites of inflammation [107]. The second stage of resolution is coupled to the biosynthesis of a new genus of lipid mediators that actively limit inflammation and promote resolution. This new genus of proresolving mediators includes lipoxins (LXs) and their aspirin-triggered carbon-15 epimers, as well as the recently discovered resolvins and protectins, which are derived from omega-3 fatty acids. An excellent review [108] on these new mediators has been published recently, and we give a summary below of the main principles described in this review.

LXs and aspirin-triggered LXs (ATLs) are considered to act as 'braking signals' in inflammation, dampening the inflammatory response. Aspirin triggers the generation of epimeric forms of LXs. Cells that express COX-2 (including activated monocytes, macrophages, and microglia) produce ATLs in response to the actions of aspirin, which triggers the endogenous formation of carbon-15 epimeric LXs. In particular, in a cytokine-primed milieu, acetylation of COX-2 by aspirin switches the catalytic activity of the enzyme to an R-lipoxygenase with the formation of 15Rhydroxyeicosatetraenoic acid, which is rapidly converted by 5 -lipoxygenase to 15 -epimeric-LXA4 or 15 -epimericLXB4.

Administration of low doses of aspirin to healthy subjects significantly increases plasma levels of ATLs, with concomitant inhibition of thromboxane biosynthesis, suggesting that ATLs may account for some of the beneficial effects of aspirin that are not strictly related to its antithrombotic actions.

The role for ATLs as anti-inflammatory molecules is well defined, with their bioactions involving the inhibition of neutrophil and eosinophil recruitment and activation. In addition, LXs and ATLs have been proposed to directly stimulate expression of genes (such as NAB1) involved in endogenous anti-inflammation and resolution, and to regulate NF- $\kappa \mathrm{B}$ activation.

The actions of LXs and ATL are not limited to counter-regulating the evolution of inflammation, as they also promote resolution at different levels. LXs stimulate monocyte chemotaxis and adherence, without causing 
degranulation or release of ROS, suggesting that the actions of LXs are related to the recruitment of monocytes to sites of injury. These monocyte activities may be host-protective. in view of the important role of these cells in wound healing and resolution at inflammatory sites. Indeed, LXs and ATLs stimulate the in vitro clearance of apoptotic cells by human monocyte-derived macrophages in a non-phlogistic manner. In addition to promoting resolution by non-phlogistic phagocytosis of apoptotic cells, LX can act to reprogram cytokine-primed macrophages from a classic pro-inflammatory phenotype to an alternatively activated phenotype.

A range of doses of aspirin (100 to $300 \mathrm{mg} /$ day) reduced the plasma levels of inflammatory biomarkers such as CRP, IL- 6 and TNF- $\alpha$ in patients with cardiovascular metabolic syndrome [109]. Aspirin was shown to reduce the levels of inflammatory cytokines, such as TNF- $\alpha$ and IL-8, but not those of negative immunoregulatory cytokines, such as IL-4 and IL-10 [110]. In the same study, there did not seem to be any effect of aspirin on IL-1 $\beta$, and the suppressant effects of aspirin on IL-6 did not reach significance. Aspirin also reduced the production of TNF- $\alpha$ in rats with streptozotocin-induced type 2 diabetes [111]. Pretreatment with aspirin in various cell types, including keloid fibroblasts and HeLa cells, significantly reduced IL- 1 and TNF- $\alpha$-induced stimulation of nuclear factor (NF-) $-\kappa \mathrm{B}[112,113]$. In patients with chronic stable angina, treatment with aspirin for 6 weeks reduced serum levels of CRP and IL-6 [114]. Another study examined the effects of 2 weeks of treatment with oral aspirin $(325 \mathrm{mg} /$ day) on the ex vivo stimulated production of IL-1 $\beta$, IL-6, and TNF- $\alpha$ by peripheral blood mononuclear cells from normal controls [115]. The authors found that oral aspirin may increase the production of cytokine-induced, but not lipopolysaccharide (LPS)-induced TNF- $\alpha$ and IL-1 $\beta$ production, suggesting that short-term treatment with aspirin might augment cytokine-induced cytokine production in normal controls. Taken together, these results provide some evidence that administration of aspirin to patients with inflammatory conditions may suppress the production of TNF- $\alpha$, IL- $1 \beta$ and maybe IL- 6 , and of acute-phase proteins such as CRP. Aspirin also seemed to reduce Th17 responses in mouse models of LPS-induced lung inflammation [116].

There is also evidence that mRNA expression of COX2 is increased in individuals with recurrent depression [117]. Likewise, a significant association was found between recurrent depression and a single-nucleotide polymorphism of the COX gene G-765C [118]. Nevertheless, as discussed above, these findings question the use of selective COX-2 inhibitors in clinical depression [102]. COX-2 has many effects, both negative and positive, on the central nervous system, meaning that the outcome of COX-2 inhibition in neuroinflammation is very difficult to predict [119]. For example, COX-2 has neuroprotective and anti-inflammatory effects, and may play a role in the integrity of the blood-brain barrier, synaptic transmission, and long-term potentiation [102,119-121]. These new data augment the view that COX-2 may not be the best target to inhibit neuroinflammation, and therefore targeting COX-1 could be a much better strategy to block neuroinflammation $[119,120]$. There are now data indicating that expression of COX-1 is enhanced in neuroinflammatory disorders, including models of $\mathrm{PD}$, and that COX-1 inhibition improves survival [122]. Taken together, these new data show that COX-1, rather than COX-2, is a key component in neurodegeneration and neuroinflammation [123]. Thus, the working spectrum of aspirin (targeting preferentially COX-1 rather than COX-2) compared with that of selective COX-2 inhibitors may be the reason why aspirin is an asset in the treatment of neuropsychiatric conditions associated with neuroinflammation and neuroprogression.

It is thus tempting to speculate that aspirin is capable of deactivating and reprogramming the activated monocytes, macrophages, and $\mathrm{T}$ cells and the neuroinflammatory responses in neuropsychiatric disorders.

\section{Aspirin and the suppression of O\&NS pathways}

There is a vast literature on the anti-inflammatory effects of asprin. Since the discovery by Vane in 1971 of the inhibitory effect of on the COX system, multiple studies have focused on the effect of aspirin on systemic peripheral O\&NS processes [124]. For example, aspirin blocks the IL-1 $\beta$-induced production of $\mathrm{NO}$ and inducible NO synthase (iNOS) [125]. In cultured smooth-muscle cells, administration of aspirin significantly reduced the expression of iNOS [126], while in rat cardiac fibroblasts, aspirin suppressed iNOS induction [127]. By contrast, other authors found that aspirin and sodium salicylate actually increased iNOS and NO production in smoothmuscle cells [128]. The potential role for aspirin in modulating levels of O\&NS pathways in the brain has received less attention. However, a number of animal studies support the contention that aspirin can act to reduce OS and prevent against oxidative damage. For example, administration of aspirin prior to acute stress exposure prevented increases in iNOS expression, TNF- $\alpha$, and markers of lipid peroxidation (such as MDA) and OS [129]. Tables 1 and 2 provide a summary of the key evidence from observational and randomized controlled trials over the past 40 years, investigating the relationship between aspirin and mental disorders.

\section{Role of aspirin in mood disorders; clinical data}

There is some evidence suggesting beneficial effects for aspirin in mood disorders, through a shortened onset of action of antidepressants [130]. However, there are negative 
Table 1 Summary of key observational studies investigating the association between aspirin use and mental illness.

\begin{tabular}{|c|c|c|c|c|c|c|c|}
\hline $\begin{array}{l}\text { Author, year; } \\
\text { study }\end{array}$ & Hypotheses & Study design & Agent and dosage & Sample & Psychiatric measure & $\begin{array}{l}\text { Presentation } \\
\text { of results }\end{array}$ & Key finding \\
\hline $\begin{array}{l}\text { Sturmer, 1996; } \\
\text { EBSHP }\end{array}$ & $\begin{array}{l}\text { ASA use } \\
\text { affected decline } \\
\text { of cognitive } \\
\text { function }\end{array}$ & Cohort study & $\begin{array}{l}\text { ASA: }<1,1 \text { to } 2 \text { and, }>2 \\
\text { tablets/day ASA effect } \\
\text { hypothesized to be more } \\
\text { dependent on frequency } \\
\text { than on dose, mean daily } \\
\text { dose was not used }\end{array}$ & $\begin{array}{l}\text { 3,631 NII >65 years old; 2,773 } \\
\text { at 3-year follow-up, and 2,023 } \\
\text { at 6-year follow-up }\end{array}$ & SPMSQ, EBMT & OR & $\begin{array}{l}\text { No significant effect seen. Modest } \\
\text { benefit of ASA, especially with } \\
\text { intermittent use, on decline of } \\
\text { cognitive function }\end{array}$ \\
\hline $\begin{array}{l}\text { Henderson, } \\
1997\end{array}$ & $\begin{array}{l}\text { ASA prevented } \\
\text { dementia or } \\
\text { cognitive } \\
\text { impairment }\end{array}$ & $\begin{array}{l}\text { Community } \\
\text { survey. Two- } \\
\text { wave: cross- } \\
\text { sectional at } 2 \\
\text { wave; } \\
\text { longitudinal } \\
\text { from } 1 \text { to } 2 \\
\text { wave }\end{array}$ & $\begin{array}{l}\text { ASA yes/no (unknown } \\
\text { dose) }\end{array}$ & $\begin{array}{l}1,045 \text { participants } 70 \text { years old } \\
\text { at baseline; } 588 \text { people with } \\
\text { cognitive assessment at both } \\
\text { waves }\end{array}$ & $\mathrm{CIE}=\mathrm{MMSE}, \mathrm{SLMT}, \mathrm{NART}$ & Mean and SD & $\begin{array}{l}\text { Cross-sectional: no significant } \\
\text { difference in cognitive tests. } \\
\text { Longitudinal: no differences in } \\
\text { cognitive decline or incidence of } \\
\text { dementia }\end{array}$ \\
\hline $\begin{array}{l}\text { Stewart, 1997; } \\
\text { BLSA }\end{array}$ & $\begin{array}{l}\text { Reduced risk of } \\
A D \text { in } A S A \text { users }\end{array}$ & Longitudinal & $\begin{array}{l}\text { ASA yes/no; NSAIDs yes/ } \\
\text { no; acetaminophen yes/ } \\
\text { no }\end{array}$ & $\begin{array}{l}\text { 1,686 participants in baseline } \\
\text { study }\end{array}$ & $\begin{array}{l}\text { BIMCT, MMES, Immediate and } \\
\text { Delayed Cued Recall, BNT, CVF, } \\
\text { TMT A and B, Clock Drawing and } \\
\text { Other constructions, CESDS, } \\
\text { PFAQ, NART }\end{array}$ & RR & $\begin{array}{l}\text { Non-significant AD risk ratio for } \\
\text { ASA users. Duration of ASA use } \\
\text { and the risk of AD were not } \\
\text { significantly associated }\end{array}$ \\
\hline $\begin{array}{l}\text { Peacock, 1999; } \\
\text { ARIC study }\end{array}$ & $\begin{array}{l}\text { Association of } \\
\text { regular use of } \\
\text { NSAIDs or ASA } \\
\text { with cognitive } \\
\text { function }\end{array}$ & $\begin{array}{l}\text { Cross-sectional } \\
\text { cohort study }\end{array}$ & $\begin{array}{l}\text { NSAIDs yes/no; ASA yes/ } \\
\text { no }\end{array}$ & $\begin{array}{l}13,153 \text { participants, } 48 \text { to } 67 \\
\text { years old }\end{array}$ & $\begin{array}{l}\text { Delayed word recall test, WAIS-R } \\
\text { digit symbol subtest, WFT }\end{array}$ & Mean & $\begin{array}{l}\text { Weak negative association }(<0.1) \\
\text { between current ASA and word } \\
\text { fluency \& recall. No association of } \\
\text { lifetime ASA and cognitive index } \\
\text { scores. ASA treatment for } 8 \text { years } \\
\text { weakly associated with better } \\
\text { word fluency }\end{array}$ \\
\hline Landi, 2003 & $\begin{array}{l}\text { Relationship } \\
\text { between NSAIDs } \\
\text { and AD }\end{array}$ & Cross-sectional & $\begin{array}{l}\text { ASA yes/no; NSAIDs yes/ } \\
\text { no }\end{array}$ & $\begin{array}{l}2,708 \text { participants admitted to } \\
\text { home care programs }\end{array}$ & CPS & Mean and SD & $\begin{array}{l}\text { NSAID users had a nearly } 50 \% \\
\text { lower risk of cognitive } \\
\text { impairment. For subjects using } \\
\text { ASA, the risk estimated was } \\
\text { similar; } 67 \% \text { decreased risk of } \\
\text { cognitive impairment associated } \\
\text { with non-ASA NSAID use }\end{array}$ \\
\hline $\begin{array}{l}\text { Nilsson, 2003; } \\
\text { OCTO-Twin }\end{array}$ & $\begin{array}{l}\text { ASA protective } \\
\text { for } A D\end{array}$ & $\begin{array}{l}\text { Cross-sectional } \\
\text { and } \\
\text { longitudinal }\end{array}$ & $\begin{array}{l}\text { Low-dose ASA (75 mg/ } \\
\text { day }+3500 \mathrm{mg} / \text { week) } \\
250,500 \mathrm{mg}\end{array}$ & $\begin{array}{l}702 \text { participants }>80 \text { years old, } \\
91 \text { with dementia at baseline; } \\
88 \text { developed dementia } \\
\text { during observational period; } \\
315 \text { people at follow-up }\end{array}$ & $\begin{array}{l}\text { DSM-III-R criteria for dementia, } \\
\text { NINCDS/ARDRA criteria for AD, } \\
\text { NINDS/AIREN criteria for vascular } \\
\text { dementia, MMSE }\end{array}$ & $\beta$ & $\begin{array}{l}\text { At 9-year follow-up, significant } \\
\text { association between ASA and } \\
\text { lower frequency of AD and all } \\
\text { dementia; significantly more likely } \\
\text { that intact cognitive function was } \\
\text { maintained in those taking ASA. } \\
\text { Use of low-dose ASA alone did } \\
\text { not affect the risk ratio }\end{array}$ \\
\hline $\begin{array}{l}\text { Cornelius, } \\
\text { 2004; } \\
\text { Kungsholmen } \\
\text { Project }\end{array}$ & $\begin{array}{l}\text { Association } \\
\text { between ASA } \\
\text { and NSAIDs with } \\
\text { AD and overall } \\
\text { dementia, and } \\
\text { influence of } \\
\text { apoE } 84\end{array}$ & $\begin{array}{l}\text { Longitudinal } \\
\text { cohort study }\end{array}$ & $\begin{array}{l}\text { ASA } 75 \text { to } 500 \mathrm{mg} / \text { day } \\
\text { yes/no; NSAIDs yes/no. } \\
\text { Differences in dosages } \\
\text { not considered }\end{array}$ & $\begin{array}{l}\text { 1,301 subjects } \geq 75 \text { years old } \\
\text { dementia-free at baseline; } 987 \\
\text { at } 1^{*} \text { follow-up ( } 314 \text { died); } 650 \\
\text { at } 2^{*} \text { follow-up ( } 281 \text { died) }\end{array}$ & $\begin{array}{l}\text { DSM III-R criteria for dementia, } \\
\text { Hachinski scale for differential } \\
\text { diagnoses AD versus VaD versus } \\
\text { Mixed dementia, MMSE, } \\
\text { neurological and psychiatric } \\
\text { examinations, neuropsychological } \\
\text { assessment }\end{array}$ & Incidence & $\begin{array}{l}\text { 6-year increased AD risk in the } \\
\text { ASA/apoE } \varepsilon 4 \text { negative group }\end{array}$ \\
\hline
\end{tabular}


Table 1 Summary of key observational studies investigating the association between aspirin use and mental illness. (Continued)

\begin{tabular}{|c|c|c|c|c|c|c|c|}
\hline $\begin{array}{l}\text { Jonker, 2004; } \\
\text { LASA }\end{array}$ & $\begin{array}{l}\text { Protective effect } \\
\text { of ASA on } \\
\text { cognitive } \\
\text { decline in older } \\
\text { people }\end{array}$ & $\begin{array}{l}\text { Community- } \\
\text { based study; ? } \\
\text { case-control }\end{array}$ & $\begin{array}{l}\text { NSAIDs yes/no; ASA <100 } \\
\text { mg yes/no }\end{array}$ & $\begin{array}{l}612 \text { participants, } 62 \text { to } 85 \\
\text { years old }\end{array}$ & MMSE, AVLT, coding task & OR & $\begin{array}{l}\text { 3-year follow-up of decline in } \\
\text { episodic memory (immediate } \\
\text { recall) for ASA users was reduced } \\
\text { by more than three times. Effect } \\
\text { of ASA was significant only in } \\
>75 \text {-year-olds }\end{array}$ \\
\hline $\begin{array}{l}\text { Shepherd, } \\
\text { 2004; SOP } \\
\text { Study }\end{array}$ & $\begin{array}{l}\text { ASA protective } \\
\text { against } A D\end{array}$ & & ASA yes/no & $\begin{array}{l}151 \mathrm{NII}, \geq 75 \text { years old, } \\
\text { dementia-free }\end{array}$ & $\begin{array}{l}\text { MMSE, Logical Memory and } \\
\text { Similarities subtest from WAIS-R, } \\
\text { BNT, visuo-perceptual abilities } \\
\text { from the JLOT, COWAT }\end{array}$ & Mean and SD & $\begin{array}{l}\text { ASA use was a significant positive } \\
\text { predictor of performance on the } \\
\text { Logical Memory test }\end{array}$ \\
\hline $\begin{array}{l}\text { Arvanitakis, } \\
\text { 2008; ROS }\end{array}$ & $\begin{array}{l}\text { Relation } \\
\text { between } \\
\text { NSAIDs/AD, } \\
\text { change in } \\
\text { cognition, and } \\
\text { AD pathology }\end{array}$ & Longitudinal & $\begin{array}{l}\text { ASA yes/no; non-ASA } \\
\text { NSAIDs yes/no }\end{array}$ & $\begin{array}{l}\text { 1,019 Catholic clergy, mean } \\
\text { age } 75 \text { years old, dementia- } \\
\text { free }\end{array}$ & As reported previously [12] & $\mathrm{HR}$ & $\begin{array}{l}\text { At } 1 \text { year-no apparent relation of } \\
\text { ASA to incident } A D \text {, change in } \\
\text { cognition, or } A D \text { pathology }\end{array}$ \\
\hline $\begin{array}{l}\text { Szekely, 2008; } \\
\text { CHCS }\end{array}$ & $\begin{array}{l}\text { Association } \\
\text { between } \\
\text { NSAIDs, ASA, } \\
\text { and } \\
\text { acetaminophen } \\
\text { with dementia } \\
\text { and AD }\end{array}$ & Prospective & $\begin{array}{l}\text { ASA yes/no; NSAIDs yes/ } \\
\text { no; acetaminophen yes/ } \\
\text { no. No dosage reported }\end{array}$ & $\begin{array}{l}3229 \text { participants }>65 \text { years } \\
\text { old, dementia-free } 1228 \text { ASA } \\
\text { users }\end{array}$ & $\begin{array}{l}\text { NINCDS/ARDRA criteria for AD, } \\
\text { ADDTC criteria for VaD, Mixed } \\
\text { dementia diagnosis, } 3 \text { MSE, MRI }\end{array}$ & OR & $\begin{array}{l}\text { At } 10 \text { years, risk of } A D, V a D \text {, and } \\
\text { all-cause dementia was not } \\
\text { associated with use of ASA }\end{array}$ \\
\hline Almeida, 2010 & $\begin{array}{l}\text { ASA decreased } \\
\text { prevalence of } \\
\text { depression and } \\
\text { cognitive } \\
\text { impairment }\end{array}$ & Retrospective & Not reported & 5,556 men 69 to 87 years old & GDS, MMSE & OR & $\begin{array}{l}\text { ASA not associated with lower OR } \\
\text { of depression or cognitive } \\
\text { impairment in }>75 \text {-year-old men. } \\
\text { Discontinuation of ASA between } \\
\text { the two assessments related to } \\
\text { greater OR of depression than } \\
\text { non-users }\end{array}$ \\
\hline $\begin{array}{l}\text { Pasco, 2010; } \\
\text { GOS }\end{array}$ & $\begin{array}{l}\text { ASA reduced } \\
\text { the risk for } \\
\text { depression; ASA } \\
+ \text { statin reduced } \\
\text { risk of de novo } \\
\text { depression }\end{array}$ & $\begin{array}{l}\text { Case-control } \\
\text { study, } \\
\text { retrospective } \\
\text { cohort analysis }\end{array}$ & ASA yes/no & $\begin{array}{l}386 \text { women }>50 \text { - years old. } \\
1 * \text { MDD }>50 \text { years old versus } \\
\text { no MDD. No prior MDD, } \\
\text { followed up from baseline or } \\
\text { time of exposure to ASA, until } \\
1^{*} \text { MDD or } 10 \text {-year follow-up }\end{array}$ & SCID I RV-NP & $\mathrm{OR}$ and $\mathrm{HR}$ & $\begin{array}{l}\text { OR for MDD in the ASA group } \\
\text { was } 0.18, P=0.1 \text { The prevalence } \\
\text { of exposure to statins + ASA was } \\
\text { lower for women with MDD; OR } \\
\text { for MDD was } 0.15 \text { ( } 95 \% \mathrm{Cl} 0.03 \text { to } \\
0.65, P=0.01 \text { ). Exposure to statins } \\
+ \text { ASA was associated with a } \\
\text { reduced risk for MDD }\end{array}$ \\
\hline $\begin{array}{l}\text { Waldstein, } \\
\text { 2010; BLSA }\end{array}$ & $\begin{array}{l}\text { Relation } \\
\text { between ASA } \\
\text { and NSAIDs and } \\
\text { age-related } \\
\text { change in } \\
\text { cognitive } \\
\text { functions }\end{array}$ & $\begin{array}{l}\text { Cross-sectional } \\
\text { and } \\
\text { longitudinal }\end{array}$ & $\begin{array}{l}\text { ASA yes/no; NSAIDs yes/ } \\
\text { no }\end{array}$ & 2300 dementia-free & $\begin{array}{l}\text { Digits Forward and Backward } \\
\text { portions of WAIS-R, CVLT, BVRT, } \\
\text { TMT, Letter \& Category Fluency, } \\
\text { BNT, MMSE, BIMCT }\end{array}$ & SE & $\begin{array}{l}\text { Cross-sectional: use of ASA related } \\
\text { to better average performance } \\
\text { across testing sessions on } \\
\text { measures of verbal and visual } \\
\text { learning, and memory and global } \\
\text { mental status. Longitudinal: ASA } \\
\text { related to greater prospective } \\
\text { decline on BIMCT and the BVRT. } \\
\text { Significant effects of ASA use } \\
\text { were noted for the BVRT, the } \\
\text { CVLT learning slope and short free } \\
\text { recall, and the MMSE, and } \\
\text { indicated better average levels of } \\
\text { function for ASA users }\end{array}$ \\
\hline
\end{tabular}


Table 1 Summary of key observational studies investigating the association between aspirin use and mental illness. (Continued)

\begin{tabular}{|c|c|c|c|c|c|c|c|}
\hline \multicolumn{8}{|c|}{ Clinical population } \\
\hline $\begin{array}{l}\text { Ketterer, 1996; } \\
\text { Coronary } \\
\text { angiography }\end{array}$ & $\begin{array}{l}\text { Regular ASA } \\
\text { prophylactic } \\
\text { therapy for IHD } \\
\text { associated with } \\
\text { emotional } \\
\text { distress }\end{array}$ & & ASA 80 to $325 \mathrm{mg}$ & 174 men & $\begin{array}{l}\text { CMS, Framingham Type A Scale, } \\
\text { KSSFC }\end{array}$ & & $\begin{array}{l}\text { ASA associated with less } \\
\text { depression and anxiety or worry } \\
\text { on the KSSFC }\end{array}$ \\
\hline $\begin{array}{l}\text { Stanford, } \\
\text { 1999; HF or } \\
\text { previouS OHT } \\
\text { or CB }\end{array}$ & & & $\begin{array}{l}\text { Usual schedule of drug } \\
\text { therapy maintained }\end{array}$ & 135 participants & Profile of Mood States & $\begin{array}{l}\text { Mean and } \\
\text { SEM }\end{array}$ & $\begin{array}{l}\text { More positive mood in ASA } \\
\text { groups due to less fatigue. } \\
\text { Tension and TMD in ASA patients } \\
\text { just failed to reach criterion for } \\
\text { statistical significance }\end{array}$ \\
\hline $\begin{array}{l}\text { Broe; 2000; } \\
\text { SOP Study } \\
\text { dementia }\end{array}$ & & Case-control & $\begin{array}{l}80 \% \text { on ASA } 175 \text { mg; no } \\
\text { high dose }\end{array}$ & $\begin{array}{l}163 \mathrm{NII} \geq 75 \text { years old with } \\
\text { different dementias categories, } \\
\text { and } 373 \text { control subjects }\end{array}$ & NINCDS-ADRDA criteria for AD & & $\begin{array}{l}\text { Inverse association between ASA } \\
\text { and } A D \text {, but not other dementia, } \\
\text { not dosage-related }\end{array}$ \\
\hline $\begin{array}{l}\text { Mendlewicz, } \\
\text { 2006; } \\
\text { treatment- } \\
\text { resistant DP }\end{array}$ & $\begin{array}{l}\text { Accelerating } \\
\text { effect of ASA in } \\
\text { combination } \\
\text { with fluoxetine }\end{array}$ & $\begin{array}{l}\text { Open-label, } \\
\text { uncontrolled }\end{array}$ & $\begin{array}{l}\text { Treated openly during } 4 \\
\text { weeks with ASA } 160 \mathrm{mg} / \\
\text { day in addition to their } \\
\text { current antidepressant } \\
\text { treatment }\end{array}$ & $\begin{array}{l}21 \text { participants underwent } \geq 4 \\
\text { weeks SSRI }\end{array}$ & HDRS & Mean and SD & $\begin{array}{l}\text { SSRI + ASA showed a global } \\
\text { response rate of } 52 \% \text {. Remission } \\
\text { was achieved in } 43 \% \text { of the total } \\
\text { sample and } 82 \% \text { of the responder } \\
\text { sample. In the responder group, a } \\
\text { significant improvement was seen } \\
\text { within week } 1 \text {, which was } \\
\text { sustained until day } 28\end{array}$ \\
\hline $\begin{array}{l}\text { Stolk, 2010; } \\
\text { bipolar } \\
\text { disorder }\end{array}$ & $\begin{array}{l}\text { NSAIDs and } \\
\text { glucocorticoids } \\
\text { ameliorate } \\
\text { bipolar } \\
\text { symptoms }\end{array}$ & & $\begin{array}{l}\text { ASA } 30 \text { or } 80 \mathrm{mg} / \text { day or } \\
\text { ASA }>80 \mathrm{mg} / \mathrm{kg} \text { or non- } \\
\text { selective NSAIDs or COX- } \\
\text { 2i or GCs + lithium }\end{array}$ & $\begin{array}{l}5145 \text { participants receiving } \\
\text { lithium }\end{array}$ & $\begin{array}{l}\text { Incidence density of medication } \\
\text { events (change in medication or } \\
\text { increase of }>30 \% \text { of the current } \\
\text { dose) }\end{array}$ & $\begin{array}{l}\text { Incidence } \\
\text { density ratio }\end{array}$ & $\begin{array}{l}\text { Subjects receiving ASA } 30 \text { or } 80 \\
\text { mg/day were } 17 \% \text { less likely to } \\
\text { have a medication event; with } \\
>80 \mathrm{mg} / \mathrm{kg} \text { ASA, non-selective } \\
\text { NSAIDs, COX-2i, and GCs were not } \\
\text { significant, but non- selective } \\
\text { NSAIDs and GCs significantly } \\
\text { increased medication events }\end{array}$ \\
\hline
\end{tabular}

3MSE, Modified Mini-Mental State Examination; AD, Alzheimer's disease; ADDTC, Alzheimer Disease Diagnostic and Treatment Centers; apoE, apolipoprotein E; ASA, acetylsalicylic acid (aspirin); AVLT, Auditory-Verbal Learning Test; BIMCT, Blessed Information-Memory-Concentration Test; BNT, Boston Naming Test; BVRT, Benton Visual Retention Test; CESDS, Center for Epidemiologic Studies Depression Scale; CIE, Canberra Interview for the Elderly; CMS, Cook-Medley Scale; COWAT, Controlled Oral Word Association Test; COX-2i, cyclooxygenase-2 inhibitor; CVF, Competing Values Framework; CVLT, California Verbal Learning Test; DSM-III-R,

Diagnostic and Statistical Manual of Mental Disorders, 3rd revision; EBMT, East Boston Memory Test; F-U, follow-up; GC, Glucocorticoids; GDS, Geriatric Depression Scale; HDRS, Hamilton Depression Rating Scale; HR, hazard ratio; IHD, ischemic heart disease; JLOT, Judgment of Line Orientation; KSSFC, Ketterer Stress Symptom Frequency Checklist; MDD, Major Depressive Disorder; MMSE, Mini-Mental State Examination; MRI, magnetic resonance imaging; NART, National Adult Reading Test; NII, Non-institutionalized individuals; NINCDS-ADRDA, National Institute of Neurological and Communicative Diseases and Stroke/Alzheimer's Disease and Related Disorders Association; NINDS/AIREN, National Institute of Neurological Disorders and Stroke and Association Internationale pour la Recherché et I'Enseignement en Neurosciences; NSAID non-steroidal antiinflammatory drug; OR, odds ratio; PFAQ, Pfeffer Activities Questionnaire; PMS, Profile of Mood States; SCID I RV-NP, Structured Clinical Interview for DSM-IV Axis I Disorders, Research Version, Non-patient; SD, standard deviation: SE, standard error: SEM, standard error of the mean; SLMT, Symbol Letter Modalities Test: SPMSQ, Short Portable Mental Status Questionnaire; SSRI, selective serotonin reuptake inhibitor; TMD, Total Mood Disturbance Score; TMT, Trail Making Test; VaD, vascular dementia; vs, versus; WAIS-R, (Wechsler Adult Intelligence Scale - Revised; WFT, Word Fluency Test. 
Table 2 Summary of key randomized controlled trials evaluating the effects of aspirin use on mental illness and symptoms.

\begin{tabular}{|c|c|c|c|c|c|c|}
\hline $\begin{array}{l}\text { Author, year; } \\
\text { study }\end{array}$ & Study design & Agent/dosage & Sample & Psych measure & $\begin{array}{l}\text { Presentation } \\
\text { of results }\end{array}$ & Key finding \\
\hline \multicolumn{7}{|c|}{ Non-clinical population } \\
\hline $\begin{array}{l}\text { Dinnerstein, } \\
1970\end{array}$ & $\mathrm{DB}-\mathrm{RCT}$ & $\begin{array}{l}\text { ASA } 600 \text { mg + placebo } \\
\text { 'energizer'/'tranquilizer' versus } \\
\text { lactose } 600 \text { mg + placebo } \\
\text { 'energizer'/'tranquilizer' }\end{array}$ & 80 healthy male college students & CMS & & $\begin{array}{l}\text { ASA had no direct and fixed effect on } \\
\text { mood, but acts to modulate the } \\
\text { effect of placebo or other contextual } \\
\text { variables }\end{array}$ \\
\hline $\begin{array}{l}\text { Lieberman, } \\
1987\end{array}$ & DB-RCT & $\begin{array}{l}2^{*} \text { to } 6^{*} \text { sessions: caffeine } 64 \mathrm{mg} \text {, } \\
\text { or ASA } 800 \mathrm{mg} \text {, or caffeine } 64 \\
\mathrm{mg}+\mathrm{ASA} 800 \mathrm{mg} \text {, or caffeine } \\
128 \mathrm{mg}+\mathrm{ASA} 800 \mathrm{mg} \text {, or } \\
\text { placebo in Latin-square design }\end{array}$ & $\begin{array}{l}20 \text { healthy men } 18 \text { to } 35 \text { years } \\
\text { old, caffeine intake }<400 \mathrm{mg} / \text { day, } \\
\text { non-smokers }\end{array}$ & $\begin{array}{l}6 \text { sessions PMS, visual analog } \\
\text { mood scales, NVMS, SSS, and } \\
\text { performance tests }\end{array}$ & $\begin{array}{l}\text { Mean and } \\
\text { SEM }\end{array}$ & $\begin{array}{l}\text { Caffeine alone and caffeine +ASA } \\
\text { improved vigilance, self-reported } \\
\text { efficiency and mood compared with } \\
\text { ASA alone and placebo }\end{array}$ \\
\hline $\begin{array}{l}\text { Kang, 2007; } \\
\text { Women's } \\
\text { Health Study }\end{array}$ & $\begin{array}{l}\text { Cohort study } \\
\text { within a DB-RCT }\end{array}$ & $\begin{array}{l}\text { ASA } 100 \mathrm{mg} \text { or placebo on } \\
\text { alternate days }\end{array}$ & 6,377 women $>65$ years old & $\begin{array}{l}\text { TICS-M, immediate and delayed } \\
\text { recalls of the EBMT and delayed } \\
\text { recall of the TICS-M, 10-word list } \\
\text { and category fluency (naming as } \\
\text { many animals as possible in } 1 \\
\text { minute) }\end{array}$ & Mean and SD & $\begin{array}{l}\text { ASA users did not differ in overall } \\
\text { performance in any of the cognitive } \\
\text { assessments, from the } 1^{*} \text { assessment } \\
\text { (after } 5.6 \text { years) to the } 3^{*} \text { (after a } \\
\text { mean } 9.6 \text { years), or in their average } \\
\text { cognitive decline during } 3 \text { to } 6 \text { years } \\
\text { of follow-up. ASA users performed } \\
\text { better in category fluency, particularly } \\
\text { in the final assessment }\end{array}$ \\
\hline Kudielka, 2007 & DB-RCT & $\begin{array}{l}\text { ASA } 100 \mathrm{mg} \text {, or propranolol } 80 \\
\text { mg, or ASA } 100 \mathrm{mg}+ \\
\text { propranolol } 80 \mathrm{mg} \text {, or placebo }\end{array}$ & 73 healthy subjects & $\begin{array}{l}\text { TSST. Cortisol from six saliva } \\
\text { samples taken before and after } \\
\text { the stress exposure }\end{array}$ & Mean and SD & $\begin{array}{l}5 \text { days: groups did not differ in their } \\
\text { cortisol responses }\end{array}$ \\
\hline \multicolumn{7}{|c|}{ Clinical population } \\
\hline $\begin{array}{l}\text { Clarke, 2003; } \\
\text { VITAL trial } \\
\text { collaborative } \\
\text { group; } \\
\text { dementia or } \\
\text { MCI }\end{array}$ & $\begin{array}{l}\text { DB-RC; 4-week } \\
\text { placebo- } \\
\text { controlled run-in } \\
\text { period before } \\
\text { randomization }+ \\
\text { 12-week } \\
\text { treatment }\end{array}$ & $\begin{array}{l}\text { ASA } 81 \text { mg, or placebo AND } \\
\text { folic acid } 2 \text { mg + vitamin B12 } 1 \\
\text { mg, or placebo AND vitamin E } \\
500 \mathrm{mg}+\text { vitamin C } 200 \mathrm{mg} \text {, or } \\
\text { placebo in } 2 \times 2 \times 2 \text { factorial } \\
\text { design }\end{array}$ & $\begin{array}{l}149 \mathrm{NII}, 12 \text { to } 26 \text { patients MMSE } \\
\text { score or <27 patients TICS-M } \\
\text { score, naïve to study medications. } \\
\text { Follow-up: } 137 \text { for biochemical } \\
\text { outcomes, } 128 \text { for cognitive } \\
\text { outcomes }\end{array}$ & TICS-M, MMSE, ADAS & $\begin{array}{l}\text { Median } \\
\text { percentage } \\
\text { reduction }\end{array}$ & $\begin{array}{l}12 \text { weeks of ASA was effective in } \\
\text { reducing biochemical factors } \\
\text { (thromboxane) associated with } \\
\text { cognitive impairment in people at risk } \\
\text { of dementia. No effect of treatment } \\
\text { on cognitive function }\end{array}$ \\
\hline $\begin{array}{l}\text { AD2000, 2008; } \\
\text { Alzheimer's } \\
\text { disease }\end{array}$ & OL-RCT & ASA 75 mg yes/no & $310 \mathrm{NII}$ & MMSE, behavioral symptoms & Mean and SD & $\begin{array}{l}\text { At } 3 \text {-year follow-up: no differences in } \\
\text { scores, significantly higher risk of } \\
\text { bleeding }\end{array}$ \\
\hline
\end{tabular}


Table 2 Summary of key randomized controlled trials evaluating the effects of aspirin use on mental illness and symptoms. (Continued)

\begin{tabular}{|c|c|c|c|c|c|c|}
\hline $\begin{array}{l}\text { Price, 2008; } \\
\text { asymptomatic } \\
\text { atherosclerosis }\end{array}$ & DB-RCT & ASA 100 mg or placebo & 3350 participants $50-75$ years old & $\begin{array}{l}\text { Summary cognitive score = tests } \\
\text { of memory, executive function, } \\
\text { non-verbal reasoning, mental } \\
\text { flexibility, and information } \\
\text { processing }\end{array}$ & Mean and SD & At 5-year follow-up: no differences \\
\hline $\begin{array}{l}\text { Gałecki, 2009; } \\
\text { first depressive } \\
\text { episode }\end{array}$ & $\mathrm{OL}-\mathrm{RCT}$ & $\begin{array}{l}\text { fluoxetine } 20 \text { mg, or fluoxetine } \\
20 \text { mg + ASA } 150 \text { mg }\end{array}$ & 77 participants & HDRS & & $\begin{array}{l}\text { No differences in HDRS between } \\
\text { fluoxetine group and fluoxetine + } \\
\text { ASA group }\end{array}$ \\
\hline $\begin{array}{l}\text { Laan, 2010; } \\
\text { schizophrenic } \\
\text { spectrum } \\
\text { disorders }\end{array}$ & DB-RCT & $\begin{array}{l}\text { ASA } 1000 \text { mg/day or placebo } \\
\text { adjuvant to antipsychotic + } \\
\text { pantoprazole } 40 \mathrm{mg} / \text { day }\end{array}$ & $\begin{array}{l}70 \text { adults } \\
\text { PANSS } \geq 60,2 \text { items } \geq 4 \text {, illness } \\
\text { duration }<10 \text { years. } 2 \text {-week } \\
\text { placebo run-in period, and only } \\
\text { those who achieved over } 80 \% \\
\text { compliance were randomized }\end{array}$ & PANSS & Mean and SD & $\begin{array}{l}\text { Adjuvant ASA reduced overall } \\
\text { psychopathology and positive } \\
\text { symptoms at } 3 \text { months. No significant } \\
\text { results in other subscales. ASA had } \\
\text { greater effect on overall } \\
\text { psychopathology in individuals with } \\
\text { more altered immune function. ASA } \\
\text { significantly reduced overall } \\
\text { psychopathology in individuals with } \\
\text { the lowest Th1:Th2 ratios }\end{array}$ \\
\hline
\end{tabular}

ADAS, Alzheimer's Disease Assessment Scale; ASA, acetylsalicylic acid (aspirin); DB, double-blind; EBMT, East Boston Memory Test; HDRS, Hamilton Depression Rating Scale; MCl, mild cognitive impairment; MMSE, Mini-Mental State Examination; NII, Non-institutionalized individuals; NVMS, Nestle Visual Analog Mood Scale; OL, open-label; PANSS, Positive and Negative Syndrome Scale; PMS, Profile of Mood States RCT,

randomized controlled trial; SD, standard deviation; SEM, standard error of the mean; SSS, Stanford Sleepiness Scale; Th, T-helper; TICS-M, Telephone Interview for Cognitive Status - Modified; TSST, Trier Social Stress Test. 
epidemiological data from a study of 5,556 older men, which showed no association between current aspirin use and depression, although the men who discontinued aspirin had a greater odds ratio for depression compared with those who had never used aspirin [131]. In a treatmentintervention study of 70 patients with depression, administration of aspirin together with fluoxetine conferred a greater reduction of OS parameters compared with fluoxetine monotherapy [132]. Another randomized controlled clinical trial is currently underway to investigate the potential benefits of aspirin as an adjunctive treatment in bipolar depression [133].

\section{Role of aspirin in schizophrenia: clinical data}

A recent study showed that aspirin reduces the core symptoms of schizophrenia [134]. Although the study had a relatively small number of participants $(n=70)$, it did show a benefit of aspirin 1,000 mg compared with placebo over 3 months of treatment. Using the Positive and Negative Symptoms Scale (PANSS), improvements were seen on the total PANSS and the positive subscale. Given the overlapping biomarker data in mood and psychotic disorders, this is an intriguing lead.

\section{Role of aspirin in Alzheimer's disease: clinical data}

A number of studies have investigated the potential role for aspirin in the treatment and prevention of $A D$, although at this stage, its therapeutic potential has not been proven. Epidemiological investigations showed that individuals who used high-dose aspirin exhibited lower rates of $\mathrm{AD}$ and improved maintenance of cognition than those who did not use the drug [135]. However, a recent systematic review and meta-analysis of controlled intervention studies failed to show an improvement in indices of cognitive decline, but did find increased bleeding rates in patients taking aspirin [136]. However, given the short-term nature of many controlled studies, it is difficult for such studies to identify the risks and benefits of aspirin for primary prevention of AD in the longer term. Some authors have suggested that, in combination with docosahexaenoic acid, administration of low-dose aspirin may 'provide multiple levels of protection against the course of Alzheimer's' [137].

\section{Conclusion}

The evidence presented in this review provides a window into a potentially new line of therapeutic targets for treating psychiatric and neurodegenerative disorders. Inflammation and OS seem to be active pathways not only in the disorders highlighted in this paper, but in other diverse medical comorbidites. Increased inflammation and OS seem to be underlying factors for each of the seemingly diverse conditions discussed in the review, and therefore, decreasing inflammation or inflammatory responses may have the potential to reduce risk and/or have therapeutic value in any or some of these disorders. Only trials will clarify this uncertainty. We are profoundly limited by phenomenologically based classifications in psychiatry, as nowhere else in medicine does phenomenology linearly reflect the underlying pathology, nor should we expect it to do so in psychiatry and related neurosciences. It is therefore unclear whether each disorder has unique patterns of inflammatory dysregulation that determine clinical symptoms, or whether these pathways are non-specific features, like pyrexia, of diverse underlying primary pathologies. This remains to be clarified. In this regard, biomarkers hold the promise of predicting therapeutic response, as there are tantalizing indications from a recent clinical trial of the TNF antagonist infliximab that treatment with anti-inflammatory agents may be beneficial only in patients with raised levels of baseline inflammatory markers [138]. Similarly, a recent cross-sectional study of 3687 men aged 69-87 years showed that older men with high homocysteine levels had a greater risk of depression, while those men who had raised homocysteine levels and were users of aspirin had a lower risk of depression [139].

There has been extensive characterization through basic science of the mechanisms by which aspirin might specifically reduce inflammation and OS and how this might subsequently lead to benefit in the clinical setting. Indeed, although there is a paucity of clinical trials investigating aspirin, the data provided thus far are promising. Randomized controlled trials of aspirin that include the analysis of biomarkers may not only provide further support for the use of aspirin, but may also serve to further characterize the underlying pathophysiology of these disorders. Further research is required to fully elucidate whether aspirin has clinical potential as an adjunctive treatment in psychiatry and neurology.

\section{Abbreviations}

ATLs: aspirin-triggered lipoxins; C4: complement component 4; CCL2: chemokine (C-C motif) ligand 2; CDC42: cell division control protein 42 homolog; COX: cyclo-oxygenase; CRP: C-reactive protein; EGR3: Early growth response protein 3; GSH-Px: glutathione peroxidase; ICAM-1: intercellular adhesion molecule 1; IL: interleukin; iNOS: Inducible nitric oxide synthase; LPS: lipopolysaccharide; LXs: lipoxins; MDA: Malondialdehyde; MDD: major depressive disorder; MDEs: major depressive episodes; MPS: mononuclear phagocyte system; MS: multiple sclerosis; NF-kB: Nuclear factor-kB, O\&NS, oxidative and nitrosative stress; OPG: osteoprotegerin; OS: oxidative stress; PAI-1: plasminogen activator inhibitor-1; PANSS: Positive and Negative Symptoms Scale; PD: Parkinson's disease; PET: positron emission tomography; PGE2: prostaglandin E2, PTX3, pentraxin-related protein; QUIN: quinolinic acid; SACC: subgenual anterior cingulate cortex; SOD: superoxide dismutase; TNF: tumor necrosis factor.

\section{Authors' contributions}

$\mathrm{MB}$ was responsible for the initial conception and drafting of the manuscript, and collating the contributions from the other authors. OD was responsible for contributing to sections pertaining to the biochemistry of 
aspirin, and also to the psychiatric clinical sections. HD was responsible for contributing to the mechanistic sections of the review. JMN and AON were responsible for contributing to the mechanistic sections, and also to the neurodegenerative clinical sections. SM and CD contributed to the biochemical and the clinical psychiatric sections. MM contributed to the underlying-pathways sections, and assisted in bringing together all the theoretical components. All authors have read and approved the final manuscript.

\section{Competing interests}

$\mathrm{MB}$ has received grant/research support from the $\mathrm{NIH}$, Cooperative Research Centre, Simons Autism Foundation, Cancer Council of Victoria, Stanley Medical Research Foundation, MBF, NHMRC, Beyond Blue, Geelong Medical Research Foundation, Bristol Myers Squibb, Eli Lilly, Glaxo SmithKline, Organon, Novartis, Mayne Pharma and Servier; has been a speaker for Astra Zeneca, Bristol Myers Squibb, Eli Lilly, Glaxo SmithKline, Janssen Cilag, Lundbeck, Merck, Pfizer, Sanofi Synthelabo, Servier, Solvay and Wyeth; and served as a consultant to Astra Zeneca, Bristol Myers Squibb, Eli Lilly, Glaxo SmithKline, Janssen Cilag, Lundbeck and Servier. OMD has received grant support from the Brain and Behavior Foundation, Simons Autism Foundation, Stanley Medical Research Institute, Lilly, NHMRC and ASBD/ Servier. SM, HAD, CGD, JJM, MM, and AO declare no conflicts of interest.

\section{Author details}

'School of Medicine, Deakin University, 75 Pigdon's Road, Waurn Ponds, Geelong, Victoria, 3216, Australia. ${ }^{2}$ Department of Psychiatry, University of Melbourne, Parkville, Victoria, 3052, Australia. ${ }^{3}$ Orygen Youth Health Research Centre, 35 Poplar Road, Parkville, Victoria, 3052, Australia. ${ }^{4}$ Florey Institute of Neuroscience and Mental Health, University of Melbourne, Parkville, Victoria, 3052, Australia. ${ }^{5}$ Department of Immunology, Erasmus Medical Center, 3015 CE Rotterdam, The Netherlands. ${ }^{6}$ School of Public Health and Preventive Medicine, Monash University, Melbourne. ${ }^{7}$ Maes Clinics@ TRIA, Bangkok, Thailand.

Received: 26 November 2012 Accepted: 18 March 2013 Published: 18 March 2013

\section{References}

1. Ginhoux F, Greter M, Leboeuf M, Nandi S, See P, Gokhan S, Mehler MF, Conway SJ, Ng LG, Stanley ER, Samokhvalov IM, Merad M: Fate mapping analysis reveals that adult microglia derive from primitive macrophages. Science 2010, 330:841-845.

2. Villagonzalo KA, Dodd S, Dean O, Gray K, Tonge B, Berk M: Oxidative pathways as a drug target for the treatment of autism. Expert Opin Ther Targets 2010, 14:1301-1310.

3. Leonard B, Maes M: Mechanistic explanations how cell-mediated immune activation, inflammation and oxidative and nitrosative stress pathways and their sequels and concomitants play a role in the pathophysiology of unipolar depression. Neurosci Biobehav Rev 2012, 36:764-785.

4. Moylan S, Maes M, Wray NR, Berk M: The neuroprogressive nature of major depressive disorder: pathways to disease evolution and resistance, and therapeutic implications. Mol Psychiatry 2012, doi: 10.1038/ mp.2012.33.

5. Berk M: Neuroprogression: pathways to progressive brain changes in bipolar disorder. Int J Neuropsychopharmacol 2009, 12:441-445.

6. Berk M, Conus P, Kapczinski F, Andreazza AC, Yücel M, Wood SJ, Pantelis C, Malhi GS, Dodd S, Bechdolf A, Amminger GP, Hickie IB, McGorry PD: From neuroprogression to neuroprotection: implications for clinical care. Med J Aust 2010, 193:S36-40.

7. Berk M, Kapczinski F, Andreazza AC, Dean OM, Giorlando F, Maes M, Yücel M, Gama CS, Dodd S, Dean B, Magalhães PV, Amminger P, McGorry P, Malhi GS: Pathways underlying neuroprogression in bipolar disorder: Focus on inflammation, oxidative stress and neurotrophic factors. Neurosci Biobehav Rev 2011, 135:804-817.

8. Maes M, Ruckoanich P, Chang YS, Mahanonda N, Berk M: Multiple aberrations in shared inflammatory and oxidative \& nitrosative stress (IO\&NS) pathways explain the co-association of depression and cardiovascular disorder (CVD), and the increased risk for CVD and due mortality in depressed patients. Prog Neuropsychopharmacol Biol Psychiatry 2011, 35:769-783.
9. Vane JR, Botting RM: The mechanism of action of aspirin. Thromb Res 2003, 110:255-258.

10. Dai $Y, G e J$ : Clinical use of aspirin in treatment and prevention of cardiovascular disease. Thrombosis 2012, 2012:245037.

11. Rothwell PM, Wilson M, Price JF, Belch JF, Meade TW, Mehta Z: Effect of daily aspirin on risk of cancer metastasis: a study of incident cancers during randomised controlled trials. Lancet 2012, 379:1591-1601.

12. Rahola JG: Somatic drugs for psychiatric diseases: aspirin or simvastatin for depression? Current Neuropharmacol 2012, 10:139-158.

13. Breese CR, Freedman R, Leonard SS: Glutamate receptor subtype expression in human postmortem brain tissue from schizophrenics and alcohol abusers. Brain Res 1995, 674:82-90.

14. Berk M, Wadee AA, Kuschke RH, O'Neill-Kerr A: Acute phase proteins in major depression. J Psychosom Res 1997, 43:529-534.

15. Pasco JA, Jacka FN, Williams LJ, Henry MJ, Nicholson GC, Kotowicz MA, Berk M: Leptin in depressed women: cross-sectional and longitudinal data from an epidemiologic study. J Affect Disord 2008, 107:221-225.

16. Dowlati Y, Herrmann N, Swardfager W, Liu H, Sham L, Reim EK, Lanctot KL: A meta-analysis of cytokines in major depression. Biol Psychiatry 2010, 67:446-457.

17. Padmos RC, Hillegers MH, Knijff EM, Vonk R, Bouvy A, Staal FJ, de Ridder D, Kupka RW, Nolen WA, Drexhage HA: A discriminating messenger RNA signature for bipolar disorder formed by an aberrant expression of inflammatory genes in monocytes. Arch Gen Psychiatry 2008, 65:395-407.

18. Drexhage RC, van der Heul-Nieuwenhuijsen L, Padmos RC, van Beveren N, Cohen D, Versnel MA, Nolen WA, Drexhage HA: Inflammatory gene expression in monocytes of patients with schizophrenia: overlap and difference with bipolar disorder. A study in naturalistically treated patients. Int J Neuropsychopharmacol 2010, 13:1369-1381.

19. Reichenberg A, Yirmiya R, Schuld A, Kraus T, Haack M, Morag A, Pollmacher T: Cytokine-associated emotional and cognitive disturbances in humans. Arch Gen Psychiatry 2001, 58:445-452.

20. Connor TJ, Leonard BE: Depression, stress and immunological activation: the role of cytokines in depressive disorders. Life Sci 1998, 62:583-606.

21. Kalivas PW, O'Brien C: Drug addiction as a pathology of staged neuroplasticity. Neuropsychopharmacology 2008, 33:166-180.

22. Basterzi AD, Aydemir C, Kisa C, Aksaray S, Tuzer V, Yazici K, Goka E: IL-6 levels decrease with SSRI treatment in patients with major depression. Hum Psychopharmacol 2005, 20:473-476.

23. Eller T, Vasar V, Shlik J, Maron E: Pro-inflammatory cytokines and treatment response to escitalopram in major depressive disorder. Prog Neuropsychopharmacol Biol Psychiatry 2008, 32:445-450.

24. Bilici M, Efe H, Koroglu MA, Uydu HA, Bekaroglu M, Deger O: Antioxidative enzyme activities and lipid peroxidation in major depression: alterations by antidepressant treatments. J Affect Disord 2001, 64:43-51.

25. Khanzode SD, Dakhale GN, Khanzode SS, Saoji A, Palasodkar R: Oxidative damage and major depression: the potential antioxidant action of selective serotonin re-uptake inhibitors. Redox Rep 2003, 8:365-370.

26. Sarandol A, Sarandol E, Eker SS, Erdinc S, Vatansever E, Kirli S: Major depressive disorder is accompanied with oxidative stress: short-term antidepressant treatment does not alter oxidative-antioxidative systems. Hum Psychopharmacol 2007, 22:67-73.

27. Selley ML: Increased (E)-4-hydroxy-2-nonenal and asymmetric dimethylarginine concentrations and decreased nitric oxide concentrations in the plasma of patients with major depression. $J$ Affect Disord 2004, 80:249-256.

28. Forlenza MJ, Miller GE: Increased serum levels of 8-hydroxy-2'deoxyguanosine in clinical depression. Psychosom Med 2006, 68:1-7.

29. Peet M, Murphy B, Shay J, Horrobin D: Depletion of omega-3 fatty acid levels in red blood cell membranes of depressive patients. Biol Psychiatry 1998, 43:315-319.

30. Maes M, De Vos N, Pioli R, Demedts P, Wauters A, Neels H, Christophe A: Lower serum vitamin E concentrations in major depression. Another marker of lowered antioxidant defenses in that illness. J Affect Disord 2000, 58:241-246.

31. Owen AJ, Batterham MJ, Probst YC, Grenyer BF, Tapsell LC: Low plasma vitamin E levels in major depression: diet or disease? Eur J Clin Nutr 2005, 59:304-306.

32. Van Hunsel F, Wauters A, Vandoolaeghe E, Neels H, Demedts P, Maes M: Lower total serum protein, albumin, and beta- and gamma-globulin in 
major and treatment-resistant depression: effects of antidepressant treatments. Psychiatry Res 1996, 65:159-169.

33. Herken H, Gurel A, Selek S, Armutcu F, Ozen ME, Bulut M, Kap O, Yumru M, Savas HA, Akyol O: Adenosine deaminase, nitric oxide, superoxide dismutase, and xanthine oxidase in patients with major depression: impact of antidepressant treatment. Arch Med Res 2007, 38:247-252.

34. Yanik M, Erel O, Kati M: The relationship between potency of oxidative stress and severity of depression. Acta Neuropsychiatrica 2004, 16:200-203.

35. Pal SN, Dandiya PC: Glutathione as a cerebral substrate in depressive behavior. Pharmacol Biochem Behav 1994, 48:845-851.

36. Verleye M, Steinschneider R, Bernard FX, Gillardin JM: Moclobemide attenuates anoxia and glutamate-induced neuronal damage in vitro independently of interaction with glutamate receptor subtypes. Brain Res 2007, 1138:30-38.

37. Lee CS, Han ES, Lee WB: Antioxidant effect of phenelzine on MPP +-induced cell viability loss in differentiated PC12 cells. Neurochem Res 2003, 28:1833-1841.

38. Eren I, Naziroglu M, Demirdas A, Celik O, Uguz AC, Altunbasak A, Ozmen I, Uz E: Venlafaxine modulates depression-induced oxidative stress in brain and medulla of rat. Neurochem Res 2007, 32:497-505.

39. Looney JM, Childs HM: The lactic acid and glutathione content of the blood of schizophrenic patients. J Clin Invest 1934, 13:963-968.

40. Ng F, Berk M, Dean O, Bush Al: Oxidative stress in psychiatric disorders: evidence base and therapeutic implications. Int J Neuropsychopharmacol 2008, 11:851-876.

41. Fullerton JM, Tiwari Y, Agahi G, Heath A, Berk M, Mitchell PB, Schofield PR: Assessing oxidative pathway genes as risk factors for bipolar disorder. Bipolar Disord 2010, 12:550-556.

42. Dean OM, van den Buuse M, Bush Al, Copolov DL, Ng F, Dodd S, Berk M: A role for glutathione in the pathophysiology of bipolar disorder and schizophrenia? Animal models and relevance to clinical practice. Current Medicinal Chemistry 2009, 16:2965-2976.

43. Berk M, Johansson S, Wray NR, Williams L, Olsson C, Haavik J, Bjerkeset O: Glutamate cysteine ligase (GCL) and self reported depression: an association study from the HUNT. J Affect Disord 2011, 131:207-213.

44. Zuckerman $L$, Weiner I: Maternal immune activation leads to behavioral and pharmacological changes in the adult offspring. J Psychiatr Res 2005, 39:311-323.

45. Brown AS: Prenatal infection as a risk factor for schizophrenia. Schizophr Bull 2006, 32:200-202.

46. Muller N, Schwarz MJ: The immune-mediated alteration of serotonin and glutamate: towards an integrated view of depression. Mol Psychiatry 2007, 12:988-1000

47. Korschenhausen DA, Hampel HJ, Ackenheil M, Penning R, Muller N: Fibrin degradation products in post mortem brain tissue of schizophrenics: a possible marker for underlying inflammatory processes. Schizophr Res 1996, 19:103-109.

48. Miller BJ, Buckley P, Seabolt W, Mellor A, Kirkpatrick B: Meta-analysis of cytokine alterations in schizophrenia: clinical status and antipsychotic effects. Biol Psychiatry 2011, 70:663-671.

49. Lin A, Kenis G, Bignotti S, Tura GJ, De Jong R, Bosmans E, Pioli R, Altamura C, Scharpe S, Maes M: The inflammatory response system in treatment-resistant schizophrenia: increased serum interleukin-6. Schizophr Res 1998, 32:9-15.

50. van Berckel BN, Bossong MG, Boellaard R, Kloet R, Schuitemaker A, Caspers E, Luurtsema G, Windhorst AD, Cahn W, Lammertsma AA, Kahn RS: Microglia activation in recent-onset schizophrenia: a quantitative (R)[11C]PK11195 positron emission tomography study. Biol Psychiatry 2008, 64:820-822

51. Barnes DE, Yaffe $K$ : The projected effect of risk factor reduction on Alzheimer's disease prevalence. Lancet Neurol 2011, 10:819-828.

52. Rubio-Perez JM, Morillas-Ruiz JM: A review: inflammatory process in Alzheimer's disease, role of cytokines. ScientificWorldJournal 2012, 2012:756357.

53. Tuppo EE, Arias HR: The role of inflammation in Alzheimer's disease. Int J Biochem Cell Biol 2005, 37:289-305.

54. Pimplikar SW, Ghosal K: Amyloid precursor protein: more than just neurodegeneration. Stem Cell Res Ther 2011, 2:39.

55. Murakami K, Irie K, Ohigashi H, Hara H, Nagao M, Shimizu T, Shirasawa T: Formation and stabilization model of the 42-mer Abeta radical: implications for the long-lasting oxidative stress in Alzheimer's disease. J Am Chem Soc 2005, 127:15168-15174.

56. Tong Y, Zhou W, Fung V, Christensen MA, Qing H, Sun X, Song W: Oxidative stress potentiates BACE1 gene expression and Abeta generation. J Neural Transm 2005, 112:455-469.

57. Puertas MC, Martinez-Martos JM, Cobo MP, Carrera MP, Mayas MD, RamirezExposito MJ: Plasma oxidative stress parameters in men and women with early stage Alzheimer type dementia. Exp Gerontol 2012, 47:625-630.

58. Venkateshappa C, Harish G, Mahadevan A, Srinivas Bharath MM, Shankar SK: Elevated oxidative stress and decreased antioxidant function in the human hippocampus and frontal cortex with increasing age: implications for neurodegeneration in Alzheimer's disease. Neurochem Res 2012, 37:1601-1614.

59. Maes M, Kubera M, Obuchowiczwa E, Goehler L, Brzeszcz J: Depression's multiple comorbidities explained by (neuro)inflammatory and oxidative \& nitrosative stress pathways. Neuro Endocrinol Lett 2011, 32:7-24.

60. Maes M, Ringel K, Kubera M, Berk M, Rybakowski J: Increased autoimmune activity against 5-HT: a key component of depression that is associated with inflammation and activation of cell-mediated immunity, and with severity and staging of depression. J Affect Disord 2012, 136:386-392.

61. Maes M, Mihaylova I, Leunis JC: Increased serum IgM antibodies directed against phosphatidyl inositol (Pi) in chronic fatigue syndrome (CFS) and major depression: evidence that an IgM-mediated immune response against $\mathrm{Pi}$ is one factor underpinning the comorbidity between both CFS and depression. Neuro Endocrinol Lett 2007, 28:861-867.

62. Maes M, Kubera M, Mihaylova I, Geffard M, Galecki P, Leunis JC, Berk M: Increased autoimmune responses against auto-epitopes modified by oxidative and nitrosative damage in depression: Implications for the pathways to chronic depression and neuroprogression. J Affect Disord 2012.

63. Maes M: The cytokine hypothesis of depression: inflammation, oxidative $\&$ nitrosative stress (IO\&NS) and leaky gut as new targets for adjunctive treatments in depression. Neuro Endocrinol Lett 2008, 29:287-291.

64. Eaton WW, Pedersen MG, Nielsen PR, Mortensen PB: Autoimmune diseases, bipolar disorder, and non-affective psychosis. Bipolar Disord 2010, 12:638-646.

65. de la Fontaine L, Schwarz MJ, Riedel M, Dehning S, Douhet A, Spellmann I, Kleindienst N, Zill P, Plischke H, Gruber R, Muller N: Investigating disease susceptibility and the negative correlation of schizophrenia and rheumatoid arthritis focusing on MIF and CD14 gene polymorphisms. Psychiatry Res 2006, 144:39-47.

66. Margutti P, Delunardo F, Ortona E: Autoantibodies associated with psychiatric disorders. Curr Neurovasc Res 2006, 3:149-157

67. Ganzinelli S, Borda E, Sterin-Borda L: Autoantibodies from schizophrenia patients induce cerebral cox-1/iNOS mRNA expression with NO/PGE2/ MMP-3 production. Int J Neuropsychopharmacol 2010, 13:293-303.

68. Strous RD, Shoenfeld Y: Schizophrenia, autoimmunity and immune system dysregulation: a comprehensive model updated and revisited. J Autoimmun 2006, 27:71-80.

69. Hillegers MH, Reichart CG, Wals M, Verhulst FC, Ormel J, Nolen WA, Drexhage HA: Signs of a higher prevalence of autoimmune thyroiditis in female offspring of bipolar parents. Eur Neuropsychopharmacol 2007, 17:394-399.

70. Vonk R, van der Schot AC, Kahn RS, Nolen WA, Drexhage HA: Is autoimmune thyroiditis part of the genetic vulnerability (or an endophenotype) for bipolar disorder? Biol Psychiatry 2007, 62:135-140.

71. Kupka RW, Nolen WA, Post RM, McElroy SL, Altshuler LL, Denicoff KD, Frye MA, Keck PE Jr, Leverich GS, Rush AJ, Suppes T, Pollio C, Drexhage HA: High rate of autoimmune thyroiditis in bipolar disorder: lack of association with lithium exposure. Biol Psychiatry 2002, 51:305-311.

72. Padmos RC, Bekris L, Knijff EM, Tiemeier H, Kupka RW, Cohen D, Nolen WA, Lernmark A, Drexhage HA: A high prevalence of organ-specific autoimmunity in patients with bipolar disorder. Biol Psychiatry 2004, 56:476-482.

73. Rothermundt M, Arolt V, Weitzsch C, Eckhoff D, Kirchner H: Immunological dysfunction in schizophrenia: a systematic approach. Neuropsychobiology 1998, 37:186-193.

74. Drexhage RC, Hoogenboezem TA, Cohen D, Versnel MA, Nolen WA, van Beveren NJ, Drexhage HA: An activated set point of T-cell and monocyte inflammatory networks in recent-onset schizophrenia patients involves both pro- and anti-inflammatory forces. Int J Neuropsychopharmacol 2011, 14:746-755. 
75. Zorrilla EP, Cannon TD, Gur RE, Kessler J: Leukocytes and organnonspecific autoantibodies in schizophrenics and their siblings: markers of vulnerability or disease? Biol Psychiatry 1996, 40:825-833.

76. Drexhage RC, Hoogenboezem TH, Versnel MA, Berghout A, Nolen WA Drexhage HA: The activation of monocyte and T cell networks in patients with bipolar disorder. Brain Behav Immun 2011, 25:1206-1213.

77. Steiner J, Bielau H, Brisch R, Danos P, Ullrich O, Mawrin C, Bernstein HG, Bogerts $B$ : Immunological aspects in the neurobiology of suicide: elevated microglial density in schizophrenia and depression is associated with suicide. J Psychiatr Res 2008, 42:151-157.

78. Bayer TA, Buslei R, Havas L, Falkai P: Evidence for activation of microglia in patients with psychiatric illnesses. Neurosci Lett 1999, 271:126-128.

79. Radewicz K, Garey LJ, Gentleman SM, Reynolds R: Increase in HLA-DR immunoreactive microglia in frontal and temporal cortex of chronic schizophrenics. J Neuropathol Exp Neurol 2000, 59:137-150.

80. Wierzba-Bobrowicz T, Lewandowska E, Lechowicz W, Stepien T, Pasennik E: Quantitative analysis of activated microglia, ramified and damage of processes in the frontal and temporal lobes of chronic schizophrenics. Folia Neuropathol 2005, 43:81-89.

81. Falke E, Han LY, Arnold SE: Absence of neurodegeneration in the thalamus and caudate of elderly patients with schizophrenia. Psychiatry Res 2000, 93:103-110.

82. Arnold SE, Trojanowski JQ, Gur RE, Blackwell P, Han LY, Choi C: Absence of neurodegeneration and neural injury in the cerebral cortex in a sample of elderly patients with schizophrenia. Arch Gen Psychiatry 1998, 55:225-232.

83. Togo $T$, Akiyama H, Kondo H, Ikeda K, Kato M, Iseki E, Kosaka K: Expression of CD40 in the brain of Alzheimer's disease and other neurological diseases. Brain Res 2000, 885:117-121.

84. Steiner J, Walter M, Gos T, Guillemin GJ, Bernstein HG, Sarnyai Z, Mawrin C, Brisch R, Bielau H, Meyer zu Schwabedissen L, Bogerts B, Myint AM: Severe depression is associated with increased microglial quinolinic acid in subregions of the anterior cingulate gyrus: evidence for an immunemodulated glutamatergic neurotransmission? J Neuroinflammation 2011, 8:94.

85. Cosenza-Nashat M, Zhao ML, Suh HS, Morgan J, Natividad R, Morgello S, Lee SC: Expression of the translocator protein of $18 \mathrm{kDa}$ by microglia, macrophages and astrocytes based on immunohistochemical localization in abnormal human brain. Neuropathol Appl Neurobiol 2009, 35:306-328.

86. Doorduin J, de Vries EF, Dierckx RA, Klein HC: PET imaging of the peripheral benzodiazepine receptor: monitoring disease progression and therapy response in neurodegenerative disorders. Curr Pharm Des 2008, 14:3297-3315.

87. Doorduin J, de Vries EF, Willemsen AT, de Groot JC, Dierckx RA, Klein HC: Neuroinflammation in schizophrenia-related psychosis: a PET study. J Nucl Med 2009, 50:1801-1807.

88. Hammoud DA, Endres CJ, Chander AR, Guilarte TR, Wong DF, Sacktor NC, McArthur JC, Pomper MG: Imaging glial cell activation with [11C]-RPK11195 in patients with AIDS. J Neurovirol 2005, 11:346-355.

89. de Vries EF, Dierckx RA, Klein HC: Nuclear imaging of inflammation in neurologic and psychiatric disorders. Curr Clin Pharmacol 2006, 1:229-242.

90. Grover VP, Pavese N, Koh SB, Wylezinska M, Saxby BK, Gerhard A, Forton DM, Brooks DJ, Thomas HC, Taylor-Robinson SD: Cerebral microglial activation in patients with hepatitis C: in vivo evidence of neuroinflammation. J Viral Hepat 2012, 19:e89-96.

91. Leong DK, Le O, Oliva L, Butterworth RF: Increased densities of binding sites for the "peripheral-type" benzodiazepine receptor ligand [3H] PK11195 in vulnerable regions of the rat brain in thiamine deficiency encephalopathy. J Cereb Blood Flow Metab 1994, 14:100-105.

92. Butterworth RF: Hepatic encephalopathy: a central neuroinflammatory disorder? Hepatology 2011, 53:1372-1376.

93. Wisor JP, Schmidt MA, Clegern WC: Evidence for neuroinflammatory and microglial changes in the cerebral response to sleep loss. Sleep 2011, 34:261-272.

94. Ekdahl CT, Kokaia Z, Lindvall O: Brain inflammation and adult neurogenesis: the dual role of microglia. Neuroscience 2009, 158:1021-1029.

95. Roumier A, Pascual O, Bechade C, Wakselman S, Poncer JC, Real E, Triller A, Bessis A: Prenatal activation of microglia induces delayed impairment of glutamatergic synaptic function. PLOS One 2008, 3:e2595.
96. Costello DA, Lyons A, Denieffe S, Browne TC, Cox FF, Lynch MA: Long term potentiation is impaired in membrane glycoprotein CD200-deficient mice: a role for Toll-like receptor activation. J Biol Chem 2011, 286:34722-34732.

97. Roumier A, Bechade C, Poncer JC, Smalla KH, Tomasello E, Vivier E, Gundelfinger ED, Triller A, Bessis A: Impaired synaptic function in the microglial KARAP/DAP12-deficient mouse. J Neurosci 2004, 24:11421-11428.

98. Liu YP, Lin HI, Tzeng SF: Tumor necrosis factor-alpha and interleukin-18 modulate neuronal cell fate in embryonic neural progenitor culture. Brain Res 2005, 1054:152-158.

99. Patterson PH: Maternal infection: window on neuroimmune interactions in fetal brain development and mental illness. Curr Opin Neurobiol 2002, 12:115-118.

100. Maes M, Fisar Z, Medina M, Scapagnini G, Nowak G, Berk M: New drug targets in depression: inflammatory, cell-mediated immune, oxidative and nitrosative stress, mitochondrial, antioxidant, and neuroprogressive pathways. And new drug candidates-Nrf2 activators and GSK-3 inhibitors. Inflammopharmacology 2012, 20:127-150.

101. Anderson G, Maes M: Schizophrenia: Linking prenatal infection to cytokines, the tryptophan catabolite (TRYCAT) pathway, NMDA receptor hypofunction, neurodevelopment and neuroprogression. Prog Neuropsychopharmacol Biol Psychiatry 2013, 42:5-19.

102. Maes M: Targeting cyclooxygenase-2 in depression is not a viable therapeutic approach and may even aggravate the pathophysiology underpinning depression. Metab Brain Dis 2012, 27:405-13.

103. Chan MM, Moore AR: Resolution of inflammation in murine autoimmune arthritis is disrupted by cyclooxygenase- 2 inhibition and restored by prostaglandin E2-mediated lipoxin A4 production. J Immunol 2010, 184:6418-6426.

104. Gallagher PJ, Castro V, Fava M, Weilburg JB, Murphy SN, Gainer VS, Churchill SE, Kohane IS, losifescu DV, Smoller JW, Perlis RH: Antidepressant response in patients with major depression exposed to NSAIDs: a pharmacovigilance study. Am J Psychiatry 2012, 169:1065-1072.

105. Asadabadi M, Mohammadi MR, Ghanizadeh A, Modabbernia A, Ashrafi M, Hassanzadeh E, Forghani S, Akhondzadeh S: Celecoxib as adjunctive treatment to risperidone in children with autistic disorder: a randomized, double-blind, placebo-controlled trial. Psychopharmacology (Berl) 2013, 225:51-59.

106. Abbasi SH, Hosseini F, Modabbernia A, Ashrafi M, Akhondzadeh S: Effect of celecoxib add-on treatment on symptoms and serum IL-6 concentrations in patients with major depressive disorder: Randomized double-blind placebo-controlled study. J Affect Disord 2012, 141:308-314.

107. Borgeat $P$, Naccache PH: Biosynthesis and biological activity of leukotriene B4. Clin Biochem 1990, 23:459-468.

108. Maderna P, Godson C: Lipoxins: resolutionary road. Br J Pharmacol 2009, 158:947-959.

109. Gao XR, Adhikari CM, Peng LY, Guo XG, Zhai YS, He XY, Zhang LY, Lin J, Zuo ZY: Efficacy of different doses of aspirin in decreasing blood levels of inflammatory markers in patients with cardiovascular metabolic syndrome. J Pharm Pharmacol 2009, 61:1505-1510.

110. Goldstein SL, Leung JC, Silverstein DM: Pro- and anti-inflammatory cytokines in chronic pediatric dialysis patients: effect of aspirin. Clin J Am Soc Nephrol 2006, 1:979-986.

111. Sun $X$, Han F, Yi J, Han L, Wang B: Effect of aspirin on the expression of hepatocyte NF-kappaB and serum TNF-alpha in streptozotocin-induced type 2 diabetic rats. J Korean Med Sci 2011, 26:765-770.

112. Zhu G, Cai J, Zhang J, Zhao Y, Xu B: Abnormal nuclear factor (NF)-kappaB signal pathway and aspirin inhibits tumor necrosis factor alpha-induced NF-kappaB activation in keloid fibroblasts. Dermatol Surg 2007, 33:697-708.

113. Kutuk O, Basaga H: Aspirin inhibits TNFalpha- and IL-1-induced NFkappaB activation and sensitizes HeLa cells to apoptosis. Cytokine 2004, 25:229-237.

114. Ikonomidis I, Andreotti F, Economou E, Stefanadis C, Toutouzas P, Nihoyannopoulos P: Increased proinflammatory cytokines in patients with chronic stable angina and their reduction by aspirin. Circulation 1999, 100:793-798.

115. Endres S, Whitaker RE, Ghorbani R, Meydani SN, Dinarello CA: Oral aspirin and ibuprofen increase cytokine-induced synthesis of IL-1 beta and of tumour necrosis factor-alpha ex vivo. Immunology 1996, 87:264-270. 
116. Moon HG, Tae YM, Kim YS, Gyu Jeon S, Oh SY, Song Gho Y, Zhu Z, Kim YK: Conversion of Th17-type into Th2-type inflammation by acetyl salicylic acid via the adenosine and uric acid pathway in the lung. Allergy 2010, 65:1093-1103.

117. Galecki P, Galecka E, Maes M, Chamielec M, Orzechowska A, Bobinska K, Lewinski A, Szemraj J: The expression of genes encoding for COX-2, MPO, iNOS, and SPLA2-IIA in patients with recurrent depressive disorder. J Affect Disord 2012, 138:360-366.

118. Galecki P, Florkowski A, Bienkiewicz M, Szemraj J: Functional polymorphism of cyclooxygenase-2 gene (G-765C) in depressive patients. Neuropsychobiology 2010, 62:116-120.

119. Minghetti L: Cyclooxygenase-2 (COX-2) in inflammatory and degenerative brain diseases. J Neuropathol Exp Neurol 2004, 63:901-910

120. Minghetti $L$ : Role of COX-2 in inflammatory and degenerative brain diseases. Subcell Biochem 2007, 42:127-141.

121. Gilroy DW, Stables M, Newson J: In vivo models to study cyclooxygenase products in health and disease: Introduction to Part III. Methods Mol Biol 2010, 644:181-188.

122. Gu XL, Long CX, Sun L, Xie C, Lin X, Cai H: Astrocytic expression of Parkinson's disease-related A53T alpha-synuclein causes neurodegeneration in mice. Mol Brain 2010, 3:12.

123. Aid S, Langenbach R, Bosetti F: Neuroinflammatory response to lipopolysaccharide is exacerbated in mice genetically deficient in cyclooxygenase-2. J Neuroinflammation 2008, 5:17.

124. Vane JR: Inhibition of prostaglandin synthesis as a mechanism of action for aspirin-like drugs. Nat New Biol 1971, 231:232-235.

125. Carnovale DE, Fukuda A, Underhill DC, Laffan JJ, Breuel KF: Aspirin dose dependently inhibits the interleukin-1 beta-stimulated increase in inducible nitric oxide synthase, nitric oxide, and prostaglandin $\mathrm{E}(2)$ production in rat ovarian dispersates cultured in vitro. Fertil Steril 2001, 75:778-784.

126. Sánchez de Miguel $L$, de Frutos T, González-Fernández F, del Pozo V, Lahoz C, Jiménez A, Rico L, García R, Aceituno E, Millás I, Gómez J, Farré J, Casado S, López-Farré A: Aspirin inhibits inducible nitric oxide synthase expression and tumour necrosis factor-alpha release by cultured smooth muscle cells. Eur J Clin Invest 1999, 29:93-99.

127. Farivar RS, Chobanian AV, Brecher P: Salicylate or aspirin inhibits the induction of the inducible nitric oxide synthase in rat cardiac fibroblasts. Circ Res 1996, 78:759-768

128. Nishio $E$, Watanabe $Y$ : Aspirin and salicylate enhances the induction of inducible nitric oxide synthase in cultured rat smooth muscle cells. Life Sci 1998, 63:429-439.

129. De Cristobal J, Madrigal JL, Lizasoain I, Lorenzo P, Leza JC, Moro MA: Aspirin inhibits stress-induced increase in plasma glutamate, brain oxidative damage and ATP fall in rats. Neuroreport 2002, 13:217-221.

130. Mendlewicz J, Kriwin P, Oswald P, Souery D, Alboni S, Brunello N: Shortened onset of action of antidepressants in major depression using acetylsalicylic acid augmentation: a pilot open-label study. Int Clin Psychopharmacol 2006, 21:227-231.

131. Almeida OP, Alfonso H, Jamrozik K, Hankey GJ, Flicker L: Aspirin use, depression, and cognitive impairment in later life: the health in men study. J Am Geriatr Soc 2010, 58:990-992.

132. Galecki P, Szemraj J, Bienkiewicz M, Zboralski K, Galecka E: Oxidative stress parameters after combined fluoxetine and acetylsalicylic acid therapy in depressive patients. Hum Psychopharmacol 2009, 24:277-286.

133. Savitz J, Preskorn S, Teague TK, Drevets D, Yates W, Drevets W: Minocycline and aspirin in the treatment of bipolar depression: a protocol for a proof-of-concept, randomised, double-blind, placebo-controlled, $2 \times 2$ clinical trial. BMJ Open 2012, 2:e000643.

134. Laan W, Grobbee DE, Selten JP, Heijnen CJ, Kahn RS, Burger H: Adjuvant aspirin therapy reduces symptoms of schizophrenia spectrum disorders: results from a randomized, double-blind, placebo-controlled trial. J Clin Psychiatry 2010, 71:520-527.

135. Nilsson SE, Johansson B, Takkinen S, Berg S, Zarit S, McClearn G Melander A: Does aspirin protect against Alzheimer's dementia? A study in a Swedish population-based sample aged $>$ or $=80$ years. Eur J Clin Pharmacol 2003, 59:313-319.

136. Jaturapatporn D, Isaac MG, McCleery J, Tabet N: Aspirin, steroidal and nonsteroidal anti-inflammatory drugs for the treatment of Alzheimer's disease. Cochrane Database Syst Rev 2012, 2:CD006378.
137. Pomponi MF, Gambassi G, Pomponi M, Masullo C: Alzheimer's disease: fatty acids we eat may be linked to a specific protection via low-dose aspirin. Aging Dis 2010, 1:37-59.

138. Raison CL, Rutherford RE, Woolwine BJ, Shuo C, Schettler P, Drake DF, Haroon E, Miller AH: A Randomized controlled trial of the tumor necrosis factor antagonist infliximab for treatment-resistant depression: the role of baseline inflammatory biomarkers. Arch Gen Psychiatry 2012, 1-11.

139. Almeida OP, Flicker L, Yeap BB, Alfonso H, McCaul K, Hankey GJ: Aspirin decreases the risk of depression in older men with high plasma homocysteine. Trans/ Psychiatry 2012, 2:e151.

\section{Pre-publication history}

The pre-publication history for this paper can be accessed here: http://www.biomedcentral.com/1741-7015/11/74/prepub

doi:10.1186/1741-7015-11-74

Cite this article as: Berk et al:: Aspirin: a review of its neurobiological properties and therapeutic potential for mental illness. BMC Medicine 2013 11:74

\section{Submit your next manuscript to BioMed Central and take full advantage of:}

- Convenient online submission

- Thorough peer review

- No space constraints or color figure charges

- Immediate publication on acceptance

- Inclusion in PubMed, CAS, Scopus and Google Scholar

- Research which is freely available for redistribution

Submit your manuscript at www.biomedcentral.com/submit
C) Biomed Central 